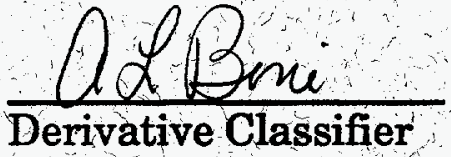

\title{
COMPARISON STUDY OF AXAIR89Q AND AXAIRQ(U)
}

A. A. Simpkins $1 / 2$

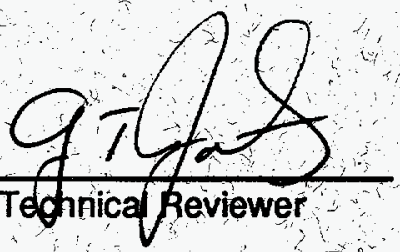

October 1995
RECEIVED

JAN 301996

OSTI
Savannah RIver Technology Center Westinghouse Savannah River Company Alken, SC 29808

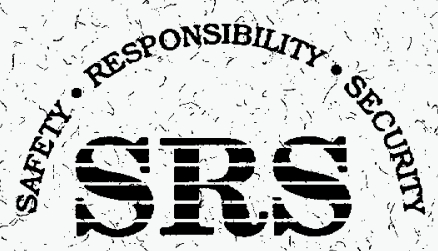

SAVANNAH RIVER SITE

PREPARED FOR THE U.S. DEPARTMENT OF ENERGY UNDER CONTRACT NO DE-ACO9-89SR18035 


\section{DISCLAIMER}

This report was prepared as an account of work sponsored by an agency of the United States Government. Neither the United States Government nor any agency thereof, nor any of their employees, makes any warranty, express or implied, or assumes any legal liability or responsibility for the accuracy, completeness, or usefulness of any information, apparatus, product, or process disclosed, or represents that its use would not infringe privately owned rights. Reference herein to any specific commercial product, process, of service by trade name, trademark, manufacturer, or otherwise does not necessarily constitute or imply endorsement, recommendation, or favoring by the United States Government or any agency thereof. The views and opinions of authors expressed herein do not necessarily state or reflect those of the United States Government or any agency thereof. 
Retention: Lifetime

\title{
COMPARISON STUDY OF AXAIR89Q AND AXAIRQ
}

\author{
A. A. Simpkins
}

Issued: October 1995

SRTC

SAVANNAH RIVER TECHNOLOGY CENTER

AIKEN, SC 29808

Westinghouse Savannah River Company

Savannah River Site

Aiken, SC 29808

PREPARED FOR THE U.S. DEPARTMENT OF ENERGY UNDER CONTRACT NO. DE-ACO9-89SR18035

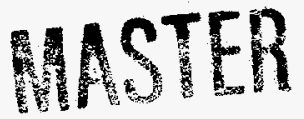

DISTRIBUTION OF THS DOCUMENT IS UALIMITED 
AXAIR89Q has been improved to incorporate many new features. The new version, AXAIRQ, contains the following improvements: inclusion of dry deposition and the ground shine pathway, 95\% dose calculations at userselected distances, availability of Pasquill-Briggs diffusion coefficients, and user-input mixing height. AXAIRQ can be executed in the same manner as AXAIR89Q by selecting certain inputs. This report shows the differences in committed effective dose equivalents (CEDEs) when the new features are invoked for various hypothetical release scenarios. 


\section{TABLE OF CONTENTS}

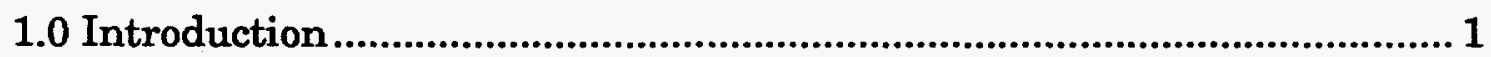

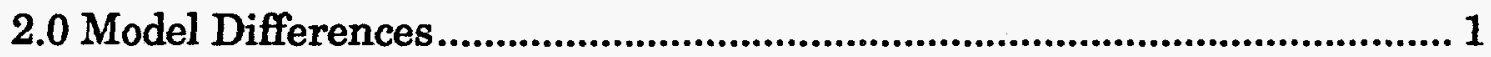

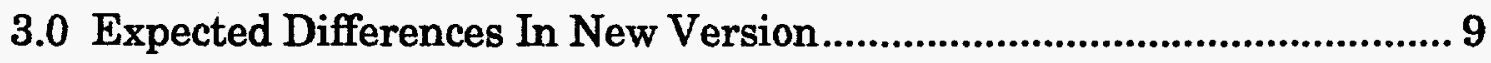

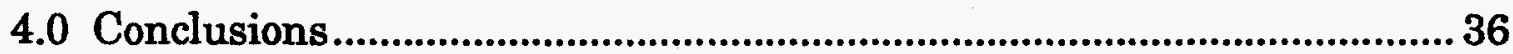

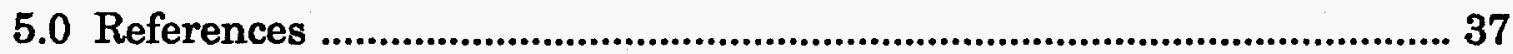


Table 1. Values of A for Horizontal Diffusion Coefficients........................ 2

Table 2. Constants used for Vertical Diffusion Coefficients...................... 3

Table 3. Classification of Atmospheric Stability ...................................... 4

Table 4. Brigg's Vertical Diffusion Coefficient Formulas ............................. 4

Table 5. Decay Constants Added to AXAIRQ Dose Factor Library ........... 8

Table 6. Location of Meteorological Towers in Site Coordinates ................ 9

Table 7. Comparison of CEDE for Ground Level Releases Using Pasquill-Briggs (PB) and Pasquill-Gifford (PG) Coefficients for 99.5\% Meteorological Conditions ............................................ 11

Table 8. Comparison of CEDE for Ground Level Releases Using PB and PG Coefficients for 50\% Meteorological Conditions

Table 9. Comparison of CEDE for Elevated Releases Using PB and PG Coefficients for 99.5\% Meteorological Conditions 14

Table 10. Comparison of CEDE for Elevated Releases Using PB and PG Coefficients for 50\% Meteorological Conditions 15

Table 11. Input for FRR EIS Sample Run 22

Table 12. AXAIR89Q vs AXAIRQ for FRR EIS Dropped Assembly Scenario (Conditions are Identical) 23

Table 13. AXAIR89Q vs AXAIRQ for FRR EIS Dropped Assembly Scenario (No Deposition, PG, Mixing Height $1000 \mathrm{~m}$ ) 24

Table 14. AXAIR89Q vs AXAIRQ for FRR EIS Dropped Assembly Scenario (No Deposition, PB, Mixing Height $200 \mathrm{~m}$ ) 24

Table 15. AXAIR89Q vs AXAIRQ for FRR EIS Dropped Assembly Scenario (Deposition, PG, Mixing Height $200 \mathrm{~m}$ ) 25

Table 16. AXAIR89Q vs AXAIRQ for FRR EIS Dropped Assembly Scenario (Deposition, PB, Mixing Height $1000 \mathrm{~m}$ ) ...................... 26

Table 17. Input for Hypothetical Center-of-Site Release 28 


\section{LIST OF FIGURES}

Figure 1. CEDE Differences Using Pasquill-Briggs vs Pasquill-

Gifford Diffusion Coefficients for a Ground-Level Release

Figure 2. CEDE Differences Using Pasquill-Briggs vs Pasquill-

Gifford Diffusion Coefficients for an Elevated Release

Figure 3. Depletion Correction Factors, Pasquill-Briggs Coefficients $\left(\mathrm{h}=0 \mathrm{~m}, \mathrm{v}_{\mathrm{d}}=0.001 \mathrm{~m} / \mathrm{s}\right.$ )

Figure 4. Depletion Correction Factors, Pasquill-Briggs Coefficients $\left(\mathrm{h}=0 \mathrm{~m}, \mathrm{v}_{\mathrm{d}}=0.01 \mathrm{~m} / \mathrm{s}\right)$

Figure 5. Depletion Correction Factors, Pasquill-Briggs Coefficients $\left(\mathrm{h}=61 \mathrm{~m}, \mathrm{v}_{\mathrm{d}}=0.001 \mathrm{~m} / \mathrm{s}\right)$.

Figure 6. Depletion Correction Factors, Pasquill-Briggs Coefficients $\left(\mathrm{h}=61 \mathrm{~m}, \mathrm{v}_{\mathrm{d}}=0.01 \mathrm{~m} / \mathrm{s}\right)$

Figure 7. Depletion Correction Factors as a Function of Wind Speed (Stability Class G, Pasquill-Briggs Coeff., $v_{d}=0.01$ )

Figure 8. Percent Differences Applying New AXAIRQ Features for FRR EIS Accident Scenario

Figure 9. Percent Differences Applying New AXAIRQ Features Ground-Level Center-of-Site release of $\mathrm{H}-3$

Figure 10. Percent Differences Applying New AXAIRQ Features

Elevated Center-of-Site Release of $\mathrm{H}-3$

Figure 11. Percent Differences Applying New AXAIRQ Features for I-131 Ground-Level Center-of-Site 32

Figure 12. Percent Differences Applying New AXAIRQ Features for I-131 Elevated Release Center-of-Site. 33

Figure 13. Percent Differences Applying New AXAIRQ Features for Pu-238 Ground-Level Center-of-Site 34

Figure 14. Percent Differences Applying New AXAIRQ Features for Pu-238 Elevated Release Center-of-Site 35 



\title{
COMPARISON STUDY OF AXAIR89Q AND AXAIRQ
}

\author{
By A. A. Simpkins \\ Westinghouse Savannah River Company \\ Savannah River Site \\ Aiken, SC 29808
}

\subsection{INTRODUCTION}

AXAIRQ (Simpkins 1995a and b) is the primary dose assessment code used at the Savannah River Site (SRS) to predict downwind doses following a hypothetical atmospheric release of relatively short duration. AXAIRQ is an improved version of AXAIR89Q. The primary improvements included in AXAIRQ are: 1) availability of Pasquill-Briggs diffusion coefficients, 2) userselected mixing height, 3) dry deposition/depletion option with ground shine pathway, and 4) ability to calculate doses for meteorological conditions not exceeded 95\% of the time, independent of sector, for user-selected distances.

Since both AXAIR89Q and AXAIRQ have a wide range of inputs, all possible combinations can not be compared. Several different scenarios have been studied that represent a certain range of conditions. The outcomes presented here should be taken to be representative only of the specific runs cited.

\subsection{MODEL DIFFERENCES}

The primary differences in methodology between AXAIR89Q and AXAIRQ are discussed.

\subsection{Diffusion Coefficients}

The user has the option of selecting diffusion coefficients developed by Pasquill-Gifford or Pasquill-Briggs. Pasquill-Briggs coefficients are more relevant to elevated releases and more experimental data were used in their development. Pasquill-Briggs diffusion coefficients were added as an option for comparison with Emergency Response code PUFF-PLUME (Garrett and Murphy 1981). Justification for use of Pasquill-Briggs coefficients at the SRS is reported in Simpkins (1994). 


\subsubsection{Pasquill-Gifford Diffusion Coefficients}

U.S. Nuclear Regulatory Commission (NRC) Regulatory Guide 1.145 (NRC 1982) provides a graphical representation of the horizontal and vertical diffusion coefficients for use in accident analysis. The horizontal and vertical diffusion coefficients as a function of downwind distance for Pasquill's atmospheric stability categories are taken directly from the Turner Workbook (1967). These curves are often referred to as Pasquill-Gifford curves or the Pasquill-Gifford-Turner formulation. These graphical representations were fitted with Eimutus' and Konicek's (1972) analytical expressions for use in AXAIR89Q. The expression used to determine horizontal diffusion coefficients is:

$$
\sigma_{y}=A x^{0.9031}
$$

where $A$ is represented by the values that are shown in Table 1 as a function of atmospheric stability and $x$ is the downwind distance in meters.

Table 1. Values of $\mathbf{A}$ for Horizontal Diffusion Coefficients

\begin{tabular}{|c|c|}
\hline Pasquill Category & $\mathrm{A}$ \\
\hline A & 0.3658 \\
B & 0.2751 \\
C & 0.2089 \\
D & 0.1471 \\
E & 0.1046 \\
F & 0.0722 \\
\hline
\end{tabular}

The equation used to determine the vertical diffusion coefficients taken from Martin and Tikvart (1968) is:

$$
\sigma_{\mathrm{z}}=A \mathbf{x}^{\mathrm{B}}+\mathrm{C}
$$

where the constants $\mathrm{A}, \mathrm{B}$, and $\mathrm{C}$ are a function of atmospheric stability and downwind distance from the source. The values of $\mathrm{A}, \mathrm{B}$ and $\mathrm{C}$ are depicted in Table 2 for various distances. 
Table 2. Constants used for Vertical Diffusion Coefficients

\begin{tabular}{|c|c|c|c|c|c|c|c|c|c|}
\hline \multirow{2}{*}{$\begin{array}{l}\text { Pas- } \\
\text { quill }\end{array}$} & \multicolumn{9}{|c|}{ Valid Range (m) } \\
\hline & \multicolumn{3}{|c|}{$<100 \mathrm{~m}$} & \multicolumn{3}{|c|}{$100-1000 \mathrm{~m}$} & \multicolumn{3}{|c|}{$>1000 \mathrm{~m}$} \\
\hline Cat. & $\bar{A}$ & B & $\mathrm{C}$ & $\bar{A}$ & $\bar{B}$ & $\mathrm{C}$ & $\overline{\mathbf{A}}$ & $\mathrm{B}$ & $\mathrm{C}$ \\
\hline $\bar{A}$ & 0.192 & 0.936 & 0 & 0.0015 & 1.941 & 9.27 & $2.4 \mathrm{e}-4$ & 2.094 & -9.6 \\
\hline B & 0.156 & 0.922 & 0 & 0.028 & 1.149 & 3.3 & 0.055 & 1.098 & 2.0 \\
\hline C & 0.116 & 0.905 & 0 & 0.113 & 0.911 & 0.0 & 0.113 & 0.911 & 0.0 \\
\hline $\mathrm{D}$ & 0.079 & 0.881 & 0 & 0.222 & 0.725 & -1.7 & 1.26 & 0.516 & -13 \\
\hline $\mathbf{E}$ & 0.063 & 0.871 & 0 & 0.211 & 0.678 & -1.3 & 6.73 & 0.305 & -34 \\
\hline$\vec{F}$ & 0.053 & 0.814 & 0 & 0.086 & 0.74 & -.035 & 18.05 & 0.18 & -48.6 \\
\hline
\end{tabular}

The vertical and horizontal diffusion coefficients for stability class $G$ are determined using the following equation (Hamby, 1990):

$$
\sigma_{\mathrm{z}}(G)=10^{\left\{2^{*} \log _{1}\left(\sigma_{\mathrm{Z}}(\mathrm{F})\right)-\log _{10}\left(\sigma_{\mathrm{Z}}(E)\right)\right\}}
$$

where

$$
\begin{array}{ll}
\sigma_{\mathbf{Z}}(E)= & \begin{array}{l}
\text { vertical diffusion coefficient at a given distance for } \\
\text { stability class } E
\end{array} \\
\sigma_{\mathbf{Z}}(E)= & \begin{array}{l}
\text { vertical diffusion coefficient at a given distance for } \\
\text { stability class } F
\end{array}
\end{array}
$$

\subsubsection{Pasquill-Briggs Diffusion Coefficients}

The equation representing Pasquill's horizontal diffusion coefficients is shown below:

where:

$$
\sigma_{\mathrm{y}}=\sigma_{\theta} \times \mathrm{f}(\mathrm{x})
$$

$$
\begin{aligned}
\sigma_{\theta} & =\text { standard deviation of lateral wind direction (radians) } \\
\mathbf{x} & =\text { downwind distance }(\mathrm{km}) \\
\mathrm{f}(\mathrm{x}) & =\text { function of distance as discussed below }
\end{aligned}
$$

Since the value of $\sigma_{\theta}$ is not readily available from the meteorological database that AXAIRQ accesses, an assumed average value of $\sigma_{\theta}$ is chosen for each atmospheric stability class as defined in NRC Regulatory Guide 1.23 (NRC 1972). Values for $\sigma_{\theta}$ are shown in Table 3. 
Pasquill developed formulations for $f(x)$ ( $x$ in $\mathrm{km}$ ) with the following equation for distances greater than $10 \mathrm{~km}$ :

$$
f(x)=0.33 \sqrt{\frac{10}{x}}
$$

Table 3. Classification of Atmospheric Stability (NRC 1972)

\begin{tabular}{|c|c|}
\hline $\begin{array}{c}\text { Pasquill } \\
\text { Category }\end{array}$ & $\begin{array}{c}\sigma_{\theta} \\
\text { (degrees) }\end{array}$ \\
\hline A & 25.0 \\
B & 20.0 \\
C & 15.0 \\
D & 10.0 \\
E & 5.0 \\
F & 2.5 \\
\hline
\end{tabular}

Pasquill developed these formulations using data from experiments at various sites. Pasquill (1976) gives a detailed description on the development of the coefficients.

At SRS, Garrett and Murphy (1981) developed an interpolating formula for values of $f(x)$ based on a table of values (Pasquill 1976) supplied by Pasquill for distances of less than or equal to $10 \mathrm{~km}$ ( $x$ in $\mathrm{km}$ ). The equation follows:

$$
f(x)=\frac{x^{-0.2}}{1.67+0.03\left[\frac{\left|1-x^{-0.2}\right|}{0.48}\right]^{0.5}}
$$

For open-country conditions, the vertical diffusion coefficients defined by Briggs (1973) and then refined by Briggs and published in Hanna (1982) are represented in Table 4 as a function of atmospheric stability.

Table 4. Brigg's Vertical Diffusion Coefficient Formulas

\begin{tabular}{|c|l|}
\hline Pasquill Type & \multicolumn{1}{|c|}{$\sigma_{\mathrm{z}}(\mathrm{x}$ in $\mathrm{m})$} \\
\hline $\mathrm{A}$ & $0.20 \mathrm{x}$ \\
$\mathrm{B}$ & $0.12 \mathrm{x}$ \\
$\mathrm{C}$ & $0.08 \mathrm{x}(1+0.0002 \mathrm{x})-0.5$ \\
$\mathrm{D}$ & $0.06 \mathrm{x}(1+0.0015 \mathrm{x})-0.5$ \\
$\mathrm{E}$ & $0.03 \mathrm{x}(1+0.0003 \mathrm{x})-1$ \\
$\mathrm{~F}$ & $0.016 \mathrm{x}(1+0.0003 \mathrm{x})-1$ \\
\hline
\end{tabular}


Different methods were reviewed for determining the value of $\sigma_{\mathrm{z}}$ for the extremely stable class $\mathrm{G}$. Values of $\sigma_{\mathrm{z}}$ for stability class $\mathrm{G}$ are extrapolated from the stability classes $\mathrm{E}$ and $\mathrm{F}$ in the same manner as in AXAIR89Q by applying equation 3 .

\subsection{Mixing Height}

The mixing height in AXAIRQ is a user-selected value with a valid range from $200-1000 \mathrm{~m}$. The vertical diffusion coefficients are limited to a value of $80 \%$ of the mixing height. Typically, the larger vertical diffusion coefficients are not associated with the $99.5 \%$ doses, but this change can affect the annual average relative air concentration thereby affecting the relative air concentrations for releases whose time periods are greater than two hours.

At SRS, comparison study of observed versus predicted mixing heights showed that the yearly average mixing height for 1978 was $1260 \mathrm{~m}$ (Garrett 1981). Monthly averages were below 1000 for only two months of the year (December and January). However, this is an average and the $200 \mathrm{~m}$ minimum value would yield conservative results.

\subsection{Plume Depletion}

Within the AXAMET95 subroutine of AXAIRQ, plume depletion factors are calculated separately for particulates and iodines. The concept of deposition velocity is used in the determination of the depletion of the plume and the ground shine dose. Deposition velocity is defined as:

$$
v_{d}=\frac{\omega}{C}=\frac{\text { deposition }}{\text { concentration }}=\frac{\mathrm{Ci} / \mathrm{m}^{2} \mathrm{~s}}{\mathrm{Ci} / \mathrm{m}^{3}}=\frac{\mathrm{m}}{\mathrm{s}}
$$

While deposition velocity is dependent on a variety of atmospheric and particle parameters, a constant value of $0.001 \mathrm{~m} / \mathrm{s}$ is assigned to particulates and $0.01 \mathrm{~m} / \mathrm{s}$ is assigned to iodines (EPA, 1991).

Though not a particulate, a deposition velocity of $0.001 \mathrm{~m} / \mathrm{s}$ is assigned to tritium, which in AXAIRQ, is assumed to be in the form of tritium oxide (Murphy and Pendergast 1979). Ground shine from tritium is not an important exposure pathway but a deposition velocity must be assigned to calculate depletion of the plume. As deposition velocity increases the percentage of tritium remaining in the plume decreases, therefore, the value chosen is conservative with respect to other values taken from literature (Feinhals and Bunnenberg, 1988). Higher values were shown for tritium 
deposition on vegetation (Murphy and Pendergast 1979) but the conservative soil deposition velocity was used.

The plume is assumed to be depleted by source depletion using the following equation (Slade 1968):

$$
\frac{Q(x)}{Q(0)}=\left[\exp \int_{0}^{x} \frac{d x}{\sigma_{z} \exp \left(h_{e}^{2} / 2 \sigma_{z}^{2}\right)}\right]^{-\left(\frac{2}{x}\right)^{0.5} \frac{v_{d}}{U_{z}}}
$$

where:

$$
\begin{aligned}
\mathbf{Q}(\mathbf{x})= & \text { residual source at distance } \mathbf{x} \text { meters downwind }(\mathrm{Ci}) \\
\mathbf{Q}(0)= & \text { source strength at release location }(\mathrm{Ci}) \\
\mathbf{x}= & \text { downwind distance }(\mathrm{m}) \\
\mathrm{h}_{\mathbf{e}}= & \text { effective release height }(\mathrm{m}) \\
\mathrm{U}_{\mathbf{S}}= & \text { wind speed at the release height }(\mathrm{m} / \mathrm{sec}) \\
\sigma_{\mathbf{Z}}= & \text { the standard deviation of the concentration distribution in the } \\
& \text { vertical direction }(\mathrm{m}) \\
\mathbf{v}_{\mathbf{d}}= & \text { deposition velocity }(\mathrm{m} / \mathrm{sec})
\end{aligned}
$$

Equation 8 is numerically integrated using the trapezoid rule. The trapezoid rule is shown below:

$$
\int_{a}^{b} f(x) d x=h\left[\frac{f(a)}{2}+f(a+h)+f(a+2 h)+\ldots+f(a+(n-1) h)+\frac{f(b)}{2}\right]
$$

where:

$a \& b=$ endpoints of the range of the integral $(a=0$ and $b=x)$

$\mathbf{h}=(\mathbf{b}-\mathbf{a}) / \mathbf{n}$

$\mathrm{n}=$ number of increments, $(100)$

While other more sophisticated methods exist for the determination of plume depletion (surface depletion models), the increase in CPU time required for these calculations may not be worth the increased accuracy.

Depletion factors are calculated for each of the 42 stability class and wind speed combinations in each sector at the given distance of interest. The 
relative air concentration is reduced by the depletion factor, as necessary, depending on the nuclide that is released. The plume is also depleted by radioactive decay in a separate subroutine. AXAIRQ includes only dry deposition and resuspension is not considered.

\subsection{Ground Shine Dose Pathway Added}

A ground shine pathway has been added for particulates and iodine. Tritium, carbon-14 and the noble gases are not included in this pathway. The model for the determination of the ground shine dose is taken from U.S. Environmental Protection Agency (EPA) (EPA 1991). Dose factors are taken from DOE/EH-0070 (DOE 1988) for the committed effective dose equivalent (CEDE). The equation used to determine the dose to an individual follows:

$$
D_{G R}=0.03171\left(V_{D}\right)\left(D F_{G R}\right)(Q)\left(\frac{\chi}{Q}\right)\left(\frac{1-e^{-\lambda t}}{\lambda}\right) D E P_{n}
$$

where:

$$
\begin{aligned}
D_{\mathrm{GR}}= & \text { ground shine dose }(\mathrm{mrem}) \\
0.03171= & \text { conversion factor }(\mu \mathrm{Ci}-\mathrm{yr} / \mathrm{Ci}-\mathrm{s}) \\
\mathrm{V}_{\mathrm{D}}= & \text { deposition velocity }(0.01 \mathrm{~m} / \mathrm{s} \text { for iodines, } 0.001 \mathrm{~m} / \mathrm{s} \text { for } \\
& \text { particulates) } \\
\mathrm{DF}_{\mathrm{GR}}= & \text { ground shine dose conversion factor }\left((\mathrm{mrem} / \mathrm{yr}) /\left(\mu \mathrm{Ci} / \mathrm{m}^{2}\right)\right) \\
\mathrm{Q}= & \text { release amount }(\mathrm{Ci}) \\
\chi / \mathrm{Q}= & \text { relative air concentration }\left(\mathrm{s}^{2} / \mathrm{m}^{3}\right) \\
\lambda= & \text { decay constant }(1 / \mathrm{s}) \\
t= & \text { duration of exposure }(4 \text { days }-345600 \mathrm{~s}) \\
\mathrm{DEP}_{\mathrm{n}}= & \text { depletion fraction for nuclide } \mathrm{n} \text { (amount of plume remaining) } \\
& \text { (unitless) }
\end{aligned}
$$

The duration of exposure (4 days) is the EPA recommended value which accounts for ingrowth of short-lived daughters in the deposited material. (EPA 1991). 


\subsubsection{Decay Constants Added to Dose Factor Library}

Changes were made to the dose factor file for the nuclides shown in Table 5 . In AXAIR89Q these nuclides were not assigned a decay constant and the assumed value was, therefore, zero. In equation 10 a decay constant of zero would result in a FORTRAN error of division by zero so the decay constants as shown in Table 5 (Walker, 1983) were added. These nuclides are not typically released from SRS, but this is one area where AXAIR89Q could differ from AXAIRQ for the same set of input conditions due to the newly assigned decay constants.

Table 5. Decay Constants Added to AXAIRQ Dose Factor Library

\begin{tabular}{|l|l|l|l|l|}
\hline Isotope & Half Life & Units & Half Life (s) & Decay (1/s) \\
\hline Si-32 & 100 & $\mathrm{y}$ & $3.154 \mathrm{E}+09$ & $2.198 \mathrm{E}-10$ \\
$\mathrm{P}-33$ & 25.3 & $\mathrm{~d}$ & $2.190 \mathrm{E}+06$ & $3.171 \mathrm{E}-07$ \\
$\mathrm{Ar}-39$ & 269 & $\mathrm{y}$ & $8.483 \mathrm{E}+09$ & $8.171 \mathrm{E}-11$ \\
$\mathrm{Cd}-113$ & 13.7 & $\mathrm{~d}$ & $1.184 \mathrm{E}+06$ & $5.856 \mathrm{E}-07$ \\
$\mathrm{In}-115$ & $4.40 \mathrm{E}+14$ & $\mathrm{y}$ & $1.388 \mathrm{E}+22$ & $4.995 \mathrm{E}-23$ \\
$\mathrm{Sm}-147$ & $1.06 \mathrm{E}+11$ & $\mathrm{y}$ & $3.343 \mathrm{E}+18$ & $2.074 \mathrm{E}-19$ \\
$\mathrm{Gd}-152$ & $1.10 \mathrm{E}+14$ & $\mathrm{y}$ & $3.469 \mathrm{E}+21$ & $1.998 \mathrm{E}-22$ \\
$\mathrm{Re}-187$ & $4.50 \mathrm{E}+10$ & $\mathrm{y}$ & $1.419 \mathrm{E}+18$ & $4.885 \mathrm{E}-19$ \\
$\mathrm{Os}-186$ & $2.00 \mathrm{E}+15$ & $\mathrm{y}$ & $6.307 \mathrm{E}+22$ & $1.099 \mathrm{E}-23$ \\
$\mathrm{~Pb}-209$ & 3.25 & $\mathrm{~h}$ & $1.170 \mathrm{E}+04$ & $5.924 \mathrm{E}-05$ \\
$\mathrm{Po}-212$ & 0.298 & $\mu \mathrm{s}$ & $2.980 \mathrm{E}-07$ & $2.326 \mathrm{E}+06$ \\
$\mathrm{Po}-218$ & 3.11 & $\mathrm{~m}$ & $1.866 \mathrm{E}+02$ & $3.715 \mathrm{E}-03$ \\
$\mathrm{Cm}-250$ & $7.40 \mathrm{E}+03$ & $\mathrm{y}$ & $2.334 \mathrm{E}+11$ & $2.970 \mathrm{E}-12$ \\
$\mathrm{Bk}-249$ & $3.20 \mathrm{E}+02$ & $\mathrm{~d}$ & $2.765 \mathrm{E}+07$ & $2.507 \mathrm{E}-08$ \\
$\mathrm{Bk}-251$ & 57 & $\mathrm{~m}$ & $3.420 \mathrm{E}+03$ & $2.027 \mathrm{E}-04$ \\
Fm-256 & 2.63 & $\mathrm{~h}$ & $9.468 \mathrm{E}+03$ & $7.321 \mathrm{E}-05$ \\
\hline
\end{tabular}

\subsection{Meteorological Tower Coordinates Updated}

The location of the meteorological towers have been updated. When AXAIR89Q was written the tower locations as of the late 1970's were used. Since that time, F and $\mathrm{H}$ Area meteorological towers were moved due to construction and forest removal near the previous location. Table 6 lists both the old and new locations of the meteorological towers (Parker and Addis 1993).

Meteorological data are used from one of the eight towers that is closest to the release point. The meteorological towers also are used as the location of the release if the user enters a specific area. For this reason, the user is 
expected to enter the exact location of the release since it is unlikely that the release occurs from the meteorological tower.

For a center-of-site release with coordinates E58000 and N62000, the new version of AXAIRQ selects the $H$ Area meteorological frequency distribution even though F Area is slightly closer. H Area is accessed because of completeness of data.

Table 6. Location of Meteorological Towers in Site Coordinates ( $\mathrm{ft}$ )

\begin{tabular}{|c|c|c|c|c|}
\hline \multirow[b]{2}{*}{$\begin{array}{l}\text { Tower } \\
\text { Location }\end{array}$} & \multicolumn{2}{|l|}{ OLD } & \multicolumn{2}{|l|}{ NEW } \\
\hline & $\begin{array}{l}\text { Easting } \\
\text { Coordinate }\end{array}$ & \begin{tabular}{l|} 
Northing \\
Coordinate
\end{tabular} & $\begin{array}{l}\text { Easting } \\
\text { Coordinate }\end{array}$ & \begin{tabular}{l|} 
Northing \\
Coordinate
\end{tabular} \\
\hline $\begin{array}{l}\mathrm{A} \\
\mathrm{C} \\
\mathrm{D} \\
\mathrm{F} \\
\mathrm{H} \\
\mathrm{K} \\
\mathrm{P} \\
\mathrm{L}\end{array}$ & $\begin{array}{l}50949.6 \\
47901.9 \\
21328.7 \\
51345.0 \\
64256.5 \\
41285.5 \\
66333.8 \\
\text { NA }\end{array}$ & $\begin{array}{l}107585.8 \\
66163.3 \\
67167.8 \\
77687.0 \\
70415.0 \\
51712.4 \\
41457.5 \\
\text { NA }\end{array}$ & $\begin{array}{l}50949.6 \\
47901.9 \\
21328.7 \\
50789.2 \\
66772.1 \\
41285.5 \\
66333.8 \\
53198.6\end{array}$ & $\begin{array}{l}107585.8 \\
66163.3 \\
67167.8 \\
76773.2 \\
68834.0 \\
51712.4 \\
41457.5 \\
46650.0 \\
\end{array}$ \\
\hline
\end{tabular}

\subsection{5\% Dose Available at User-Distances.}

A new feature in AXAIRQ is the ability to predict doses for meteorological conditions not exceeded $95 \%$ of the time at user-selected distances and the site boundary. Previously, the $95 \% \chi / Q$ was calculated only for the site boundary.

\subsection{EXPECTED DIFFERENCES IN NEW VERSION}

Hypothetical accident scenarios were analyzed to determine the affects of the changes to the code. The differences that are noted are specific to the individual runs analyzed and no conclusions can be drawn as to the outcome of other release areas with different parameters. A standard set of cases were compared and larger or smaller differences may be seen depending on release area, height, nuclide released, etc.

\subsection{Diffusion Coefficients}

Individual CEDEs are compared applying Pasquill-Gifford and PasquillBriggs diffusion coefficients with all other parameters being held constant. 
The example is for a $1 \mathrm{Ci}$ release of tritium. Both elevated $(61 \mathrm{~m})$ and ground level releases are analyzed at various distances.

Table 7 shows the comparison of the CEDE for the maximally exposed individual with meteorological conditions not exceeded $99.5 \%$ of the time in the worst case sector for a ground-level release. The differences in dose from area to area are due to the differences in meteorological conditions.

For a distance of $100 \mathrm{~m}$ or 0.06 miles from the release point, the average increase in $99.5 \%$ dose by using of Pasquill-Briggs diffusion coefficients is about 55\%. C Area has the greatest differences with a $67 \%$ increase. For a distance of $640 \mathrm{~m}$ or 0.4 miles from the release point, the average increase in dose by using Pasquill-Briggs diffusion coefficients is 36\%. The differences cover a wide range: 4-58\%. For the boundary dose calculations, the average is not shown since the boundary distance is different for each area. Percent differences range from 8-121\% for the various areas.

Table 8 shows the comparison of CEDEs for meteorological conditions that are not exceeded $50 \%$ of the time, independent of sector. For a downwind distance of $100 \mathrm{~m}$, applying Pasquill-Briggs coefficients reduces the CEDE for all areas with the average decrease of $38 \%$. For a downwind distance of 640 $\mathrm{m}$, the average decrease in CEDE due to the use of Pasquill-Briggs versus Pasquill-Gifford diffusion coefficients is $35 \%$. At the boundary, differences are less than 15\% (increase or decrease) for all areas.

Figure 1 shows a pictorial representation of the results presented in Tables 7 and 8. 
Table 7. Comparison of CEDE for Ground Level Releases Using PasquillBriggs (PB) and Pasquill-Gifford (PG) Coefficients for 99.5\% Met. Conditions

\begin{tabular}{|c|c|c|c|c|}
\hline Downwind & \multicolumn{4}{|c|}{ GROUND LEVEL RELEASE } \\
\hline $100 \mathrm{~m}$ & Area & 99.5\% Dose PG & 99.5\% Dose PB & $\begin{array}{l}\text { \% Difference } \\
\text { PB-PG } \\
\text { PG }\end{array}$ \\
\hline & $\begin{array}{l}\mathbf{A} \\
\mathbf{C} \\
\mathbf{D} \\
\mathbf{F} \\
\mathbf{H} \\
\mathbf{K} \\
\mathbf{P}\end{array}$ & $\begin{array}{l}2.84 \mathrm{E}-04 \\
2.93 \mathrm{E}-04 \\
2.61 \mathrm{E}-04 \\
2.62 \mathrm{E}-04 \\
2.65 \mathrm{E}-04 \\
2.91 \mathrm{E}-04 \\
3.10 \mathrm{E}-04\end{array}$ & $\begin{array}{c}4.33 \mathrm{E}-04 \\
4.91 \mathrm{E}-04 \\
3.79 \mathrm{E}-04 \\
4.05 \mathrm{E}-04 \\
4.06 \mathrm{E}-04 \\
4.67 \mathrm{E}-04 \\
4.80 \mathrm{E}-04 \\
\text { AVERAGE } \\
\text { Standard Dev }\end{array}$ & \begin{tabular}{c|}
$\mathbf{5 2 . 4 6 \%}$ \\
$\mathbf{6 7 . 5 8 \%}$ \\
$\mathbf{4 5 . 2 1 \%}$ \\
$\mathbf{5 4 . 5 8 \%}$ \\
$\mathbf{5 3 . 2 1 \%}$ \\
$\mathbf{6 0 . 4 8 \%}$ \\
$\mathbf{5 4 . 8 4 \%}$ \\
$\mathbf{5 5 . 4 8 \%}$ \\
$\mathbf{6 . 9 8 \%}$ \\
\end{tabular} \\
\hline $640 \mathrm{~m}$ & Area & 99.5\% Dose PG & 99.5\% Dose PB & \% Difference \\
\hline & $\begin{array}{l}\text { A } \\
\text { C } \\
\text { D } \\
\text { F } \\
\text { H } \\
\text { K } \\
\mathbf{P}\end{array}$ & $\begin{array}{l}1.80 \mathrm{E}-05 \\
2.28 \mathrm{E}-05 \\
2.00 \mathrm{E}-05 \\
1.91 \mathrm{E}-05 \\
1.96 \mathrm{E}-05 \\
2.13 \mathrm{E}-05 \\
2.26 \mathrm{E}-05\end{array}$ & $\begin{array}{c}\text { 2.79E-05 } \\
3.53 \mathrm{E}-05 \\
2.08 \mathrm{E}-05 \\
2.27 \mathrm{E}-05 \\
2.18 \mathrm{E}-05 \\
3.25 \mathrm{E}-05 \\
3.57 \mathrm{E}-05 \\
\text { AVERAGE } \\
\text { Standard Dev }\end{array}$ & \begin{tabular}{|c|}
$55.00 \%$ \\
$54.82 \%$ \\
$4.00 \%$ \\
$18.85 \%$ \\
$11.22 \%$ \\
$52.58 \%$ \\
$57.96 \%$ \\
$36.35 \%$ \\
$23.82 \%$ \\
\end{tabular} \\
\hline Boundary & Area & 99.5\% Dose PG & $99.5 \%$ Dose PB & $\%$ Difference \\
\hline & $\begin{array}{l}\text { A } \\
\text { C } \\
\text { D } \\
\text { F } \\
\text { H } \\
\mathbf{K} \\
\mathbf{P}\end{array}$ & $\begin{array}{l}2.95 \mathrm{E}-05 \\
3.04 \mathrm{E}-07 \\
2.99 \mathrm{E}-06 \\
2.71 \mathrm{E}-07 \\
2.02 \mathrm{E}-07 \\
3.02 \mathrm{E}-07 \\
4.25 \mathrm{E}-07\end{array}$ & $\begin{array}{l}3.32 \mathrm{E}-05 \\
6.46 \mathrm{E}-07 \\
3.22 \mathrm{E}-06 \\
5.49 \mathrm{E}-07 \\
3.70 \mathrm{E}-07 \\
6.67 \mathrm{E}-07 \\
7.79 \mathrm{E}-07\end{array}$ & $\begin{array}{c}12.54 \% \\
112.50 \% \\
7.69 \% \\
102.58 \% \\
83.17 \% \\
120.86 \% \\
83.29 \%\end{array}$ \\
\hline
\end{tabular}


Table 8. Comparison of CEDE for Ground Level Releases Using PB and PG Coefficients for $50 \%$ Meteorological Conditions

\begin{tabular}{|c|c|c|c|c|}
\hline Downwind & \multicolumn{4}{|c|}{ GROUND LEVEL RELEASE } \\
\hline $100 \mathrm{~m}$ & Area & 50\% Dose PG & 50\% Dose PB & $\begin{array}{l}\text { \% Difference } \\
\text { PB-PG } \\
\text { PG }\end{array}$ \\
\hline & $\begin{array}{l}\text { A } \\
\text { C } \\
\text { D } \\
\text { F } \\
\text { H } \\
\text { K } \\
\text { P }\end{array}$ & $\begin{array}{l}9.20 \mathrm{E}-05 \\
9.58 \mathrm{E}-05 \\
9.63 \mathrm{E}-05 \\
1.03 \mathrm{E}-04 \\
9.22 \mathrm{E}-05 \\
9.10 \mathrm{E}-05 \\
9.64 \mathrm{E}-05\end{array}$ & $\begin{array}{c}5.72 E-05 \\
5.96 E-05 \\
5.98 E-05 \\
6.23 E-05 \\
5.73 E-05 \\
5.66 E-05 \\
6.00 E-05 \\
\text { AVERAGE } \\
\text { Standard Dev }\end{array}$ & $\begin{array}{r}-\mathbf{3 7 . 8 3 \%} \\
-\mathbf{3 7 . 7 9 \%} \\
-37.90 \% \\
-39.51 \% \\
-37.85 \% \\
-37.80 \% \\
-37.76 \% \\
-38.06 \% \\
\mathbf{0 . 6 4 \%}\end{array}$ \\
\hline $640 \mathrm{~m}$ & Area & 50\% Dose PG & $50 \%$ Dose PB & \% Difference \\
\hline & $\begin{array}{l}\mathbf{A} \\
\mathbf{C} \\
\mathbf{D} \\
\mathbf{F} \\
\mathbf{H} \\
\mathbf{K} \\
\mathbf{P}\end{array}$ & $\begin{array}{l}\text { 4.93E-06 } \\
\text { 5.34E-06 } \\
4.99 E-06 \\
6.48 E-06 \\
4.89 E-06 \\
5.22 E-06 \\
5.38 E-06\end{array}$ & $\begin{array}{c}\text { 3.12E-06 } \\
\text { 3.53E-06 } \\
\text { 3.16E-06 } \\
\text { 4.30E-06 } \\
\text { 3.10E-06 } \\
\text { 3.45E-06 } \\
\text { 3.56E-06 } \\
\text { AVERAGE } \\
\text { Standard Dev. }\end{array}$ & $\begin{array}{r}-36.71 \% \\
-33.90 \% \\
-36.67 \% \\
-33.64 \% \\
-36.61 \% \\
-33.91 \% \\
-33.83 \% \\
-35.04 \% \\
1.52 \%\end{array}$ \\
\hline Boundary & Area & $50 \%$ Dose PG & $50 \%$ Dose PB & \% Difference \\
\hline & $\begin{array}{l}\mathbf{A} \\
\mathbf{C} \\
\mathbf{D} \\
\mathbf{F} \\
\mathbf{H} \\
\mathbf{K} \\
\mathbf{P}\end{array}$ & $\begin{array}{l}\text { 5.08E-07 } \\
2.84 \mathrm{E}-08 \\
7.47 \mathrm{E}-08 \\
\text { 3.55E-08 } \\
2.78 \mathrm{E}-08 \\
2.99 \mathrm{E}-08 \\
\text { 3.48E-08 }\end{array}$ & $\begin{array}{l}4.34 \mathrm{E}-07 \\
3.20 \mathrm{E}-08 \\
7.72 \mathrm{E}-08 \\
3.82 \mathrm{E}-08 \\
3.17 \mathrm{E}-08 \\
3.24 \mathrm{E}-08 \\
3.89 \mathrm{E}-08\end{array}$ & $\begin{array}{r}-14.57 \% \\
12.68 \% \\
3.35 \% \\
7.61 \% \\
14.03 \% \\
8.36 \% \\
11.78 \%\end{array}$ \\
\hline
\end{tabular}


Figure 1. CEDE Differences Using Pasquill-Briggs vs Pasquill-Gifford Diffusion Coefficients for a Ground-Level Release

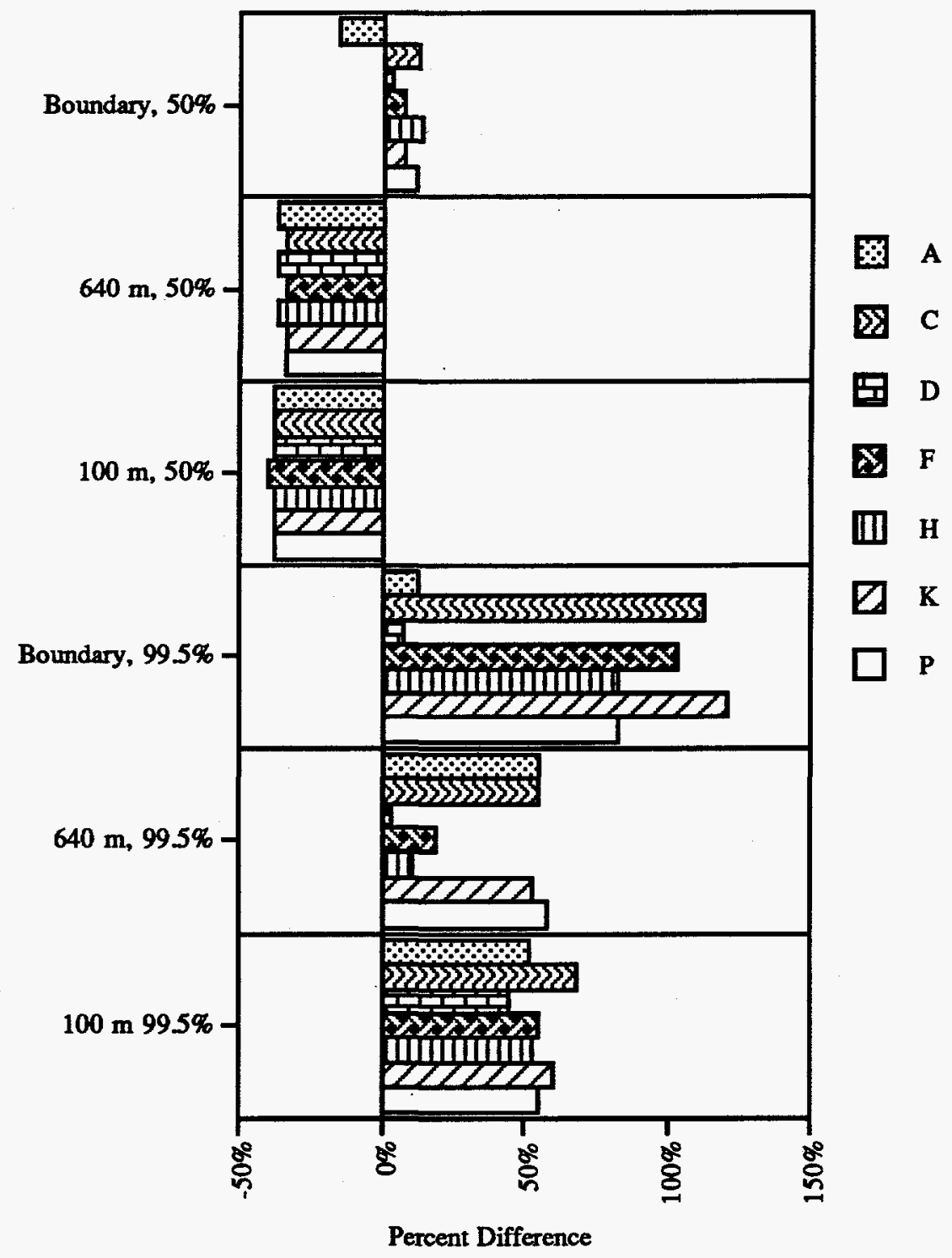


For elevated releases, the CEDE produced by utilizing Pasquill-Gifford and Pasquill-Briggs diffusion coefficients also were compared. The results are shown in Table 9 for meteorological conditions not exceeded 99.5\% of the time.

For a distance of $100 \mathrm{~m}$, the use of Pasquill-Briggs diffusion coefficients decreased the 99.5\% CEDE for all but one of the release locations, with an average percent difference of $-6 \%$. For a distance of $640 \mathrm{~m}$ from the release location, the average increase in the $99.5 \%$ CEDE was $19 \%$ with a range of $0 \%$ to $35 \%$. At the site boundary, differences in $99.5 \%$ CEDE ranged from $4 \%$ to $150 \%$ when comparing CEDEs calculated using Pasquill-Gifford and Pasquill-Briggs diffusion coefficients.

Table 9. Comparison of CEDE for Elevated Releases Using PB and PG Coefficients for $\mathbf{9 9 . 5 \%}$ Meteorological Conditions

\begin{tabular}{|c|c|c|c|c|}
\hline Downwind & \multicolumn{4}{|c|}{ ELEVATED RELEASE } \\
\hline $100 \mathrm{~m}$ & Area & 99.5\% Dose PG & 99.5\% Dose PB & $\begin{array}{c}\text { \% Difference } \\
\frac{\text { PB-PG }}{\text { PG }}\end{array}$ \\
\hline & $\begin{array}{l}\text { A } \\
\text { C } \\
\text { D } \\
\text { F } \\
\text { H } \\
\text { K } \\
\text { P }\end{array}$ & $\begin{array}{l}2.43 \mathrm{E}-05 \\
2.22 \mathrm{E}-05 \\
2.74 \mathrm{E}-05 \\
2.53 \mathrm{E}-05 \\
2.72 \mathrm{E}-05 \\
2.18 \mathrm{E}-05 \\
2.51 \mathrm{E}-05\end{array}$ & $\begin{array}{c}2.59 \mathrm{E}-05 \\
2.66 \mathrm{E}-05 \\
2.75 \mathrm{E}-05 \\
2.54 \mathrm{E}-05 \\
2.65 \mathrm{E}-05 \\
2.48 \mathrm{E}-05 \\
2.74 \mathrm{E}-05 \\
\text { AVERAGE } \\
\text { Standard Dev }\end{array}$ & $\begin{array}{r}6.58 \% \\
19.82 \% \\
0.36 \% \\
0.40 \% \\
-2.57 \% \\
13.76 \% \\
9.16 \% \\
6.79 \% \\
8.10 \%\end{array}$ \\
\hline $640 \mathrm{~m}$ & Area & 99.5\% Dose PG & 99.5\% Dose PB & \% Difference \\
\hline & $\begin{array}{l}\mathbf{A} \\
\mathbf{C} \\
\mathbf{D} \\
\mathbf{F} \\
\mathbf{H} \\
\mathbf{K} \\
\mathbf{P}\end{array}$ & $\begin{array}{l}\text { 3.70E-06 } \\
3.44 \mathrm{E}-06 \\
3.85 \mathrm{E}-06 \\
3.68 \mathrm{E}-06 \\
\text { 3.96E-06 } \\
\text { 3.44E-06 } \\
\text { 3.60E-06 }\end{array}$ & $\begin{array}{c}\text { 3.70E-06 } \\
4.64 \mathrm{E}-06 \\
4.85 \mathrm{E}-06 \\
3.74 \mathrm{E}-06 \\
4.42 \mathrm{E}-06 \\
4.19 \mathrm{E}-06 \\
4.81 \mathrm{E}-06 \\
\text { AVERAGE } \\
\text { Standard Dev }\end{array}$ & $\begin{array}{r}0.00 \% \\
34.88 \% \\
25.97 \% \\
1.63 \% \\
11.62 \% \\
21.80 \% \\
33.61 \% \\
18.50 \% \\
14.36 \%\end{array}$ \\
\hline Boundary & Area & $99.5 \%$ Dose PG & 99.5\% Dose PB & \% Difference \\
\hline & $\begin{array}{l}\mathbf{A} \\
\mathbf{C} \\
\mathbf{D} \\
\mathbf{F} \\
\mathbf{H} \\
\mathbf{K} \\
\mathbf{P}\end{array}$ & $\begin{array}{l}5.43 \mathrm{E}-06 \\
1.20 \mathrm{E}-07 \\
1.17 \mathrm{E}-06 \\
1.65 \mathrm{E}-07 \\
1.26 \mathrm{E}-07 \\
1.15 \mathrm{E}-07 \\
1.64 \mathrm{E}-07\end{array}$ & $\begin{array}{l}\text { 5.62E-06 } \\
3.07 \mathrm{E}-07 \\
1.60 \mathrm{E}-06 \\
2.78 \mathrm{E}-07 \\
2.60 \mathrm{E}-07 \\
2.18 \mathrm{E}-07 \\
2.72 \mathrm{E}-07\end{array}$ & $\begin{array}{r}3.50 \% \\
155.83 \% \\
36.75 \% \\
68.48 \% \\
106.35 \% \\
89.57 \% \\
65.85 \%\end{array}$ \\
\hline
\end{tabular}


The results for the CEDE for meteorological conditions not exceeded $50 \%$ of the time are shown in Table 10 . At $100 \mathrm{~m}$ and $640 \mathrm{~m}$ a decrease in $50 \%$ CEDE is seen for all release areas. For CEDEs at the site boundary, differences range from $-26 \%$ to $10 \%$. The results of Tables 9 and 10 are depicted graphically in Figure 2.

Table 10. CEDE Comparison for Elevated Releases Using PB and PG Coefficients for $50 \%$ Meteorological Conditions

\begin{tabular}{|c|c|c|c|c|}
\hline Downwind & \multicolumn{4}{|c|}{ ELEVATED RELEASES } \\
\hline 0.06 miles & Area & $50 \%$ Dose PG & $50 \%$ Dose PB & $\begin{array}{l}\text { \% Difference } \\
\frac{\text { PB-PG }}{\text { PG }}\end{array}$ \\
\hline & $\begin{array}{l}\mathbf{A} \\
\mathbf{C} \\
\mathbf{D} \\
\mathbf{F} \\
\mathbf{H} \\
\mathbf{K} \\
\mathbf{P}\end{array}$ & $\begin{array}{l}1.03 \mathrm{E}-05 \\
1.03 \mathrm{E}-05 \\
1.18 \mathrm{E}-05 \\
1.03 \mathrm{E}-05 \\
1.07 \mathrm{E}-05 \\
1.00 \mathrm{E}-05 \\
1.03 \mathrm{E}-05\end{array}$ & $\begin{array}{c}6.95 E-06 \\
6.99 \mathrm{E}-06 \\
7.60 \mathrm{E}-06 \\
7.03 \mathrm{E}-06 \\
7.14 \mathrm{E}-06 \\
6.81 \mathrm{E}-06 \\
6.94 \mathrm{E}-06 \\
\text { AVERAGE } \\
\text { Standard Dev }\end{array}$ & $\begin{array}{c}-32.52 \% \\
-32.14 \% \\
-35.59 \% \\
-31.75 \% \\
-33.27 \% \\
-31.90 \% \\
-32.62 \% \\
-32.83 \% \\
1.32 \%\end{array}$ \\
\hline 0.4 miles & Area & $50 \%$ Dose PG & $50 \%$ Dose PB & \% Difference \\
\hline & $\begin{array}{l}\mathbf{A} \\
\mathbf{C} \\
\mathbf{D} \\
\mathbf{F} \\
\mathbf{H} \\
\mathbf{K} \\
\mathbf{P}\end{array}$ & $\begin{array}{l}1.81 \mathrm{E}-06 \\
1.79 \mathrm{E}-06 \\
1.95 \mathrm{E}-06 \\
1.79 \mathrm{E}-06 \\
1.93 \mathrm{E}-06 \\
1.76 \mathrm{E}-06 \\
1.80 \mathrm{E}-06\end{array}$ & $\begin{array}{c}1.42 \mathrm{E}-06 \\
1.42 \mathrm{E}-06 \\
1.52 \mathrm{E}-06 \\
1.44 \mathrm{E}-06 \\
1.55 \mathrm{E}-06 \\
1.40 \mathrm{E}-06 \\
1.42 \mathrm{E}-06 \\
\text { AVERAGE } \\
\text { Standard Dev. }\end{array}$ & $\begin{array}{c}-21.55 \% \\
-20.67 \% \\
-22.05 \% \\
-19.55 \% \\
-19.69 \% \\
-20.45 \% \\
-21.11 \% \\
-20.73 \% \\
0.92 \%\end{array}$ \\
\hline Boundary & Area & $50 \%$ Dose PG & $50 \%$ Dose PB & \% Difference \\
\hline & $\begin{array}{l}\mathbf{A} \\
\mathbf{C} \\
\mathbf{D} \\
\mathbf{F} \\
\mathbf{H} \\
\mathbf{K} \\
\mathbf{P}\end{array}$ & $\begin{array}{l}3.73 \mathrm{E}-07 \\
2.34 \mathrm{E}-08 \\
5.90 \mathrm{E}-08 \\
2.90 \mathrm{E}-08 \\
2.25 \mathrm{E}-08 \\
2.44 \mathrm{E}-08 \\
2.87 \mathrm{E}-08\end{array}$ & $\begin{array}{l}2.74 \text { E-07 } \\
2.58 E-08 \\
5.09 E-08 \\
2.93 E-08 \\
2.39 E-08 \\
2.63 E-08 \\
2.92 E-08\end{array}$ & $\begin{array}{r}-26.54 \% \\
10.26 \% \\
-13.73 \% \\
1.03 \% \\
6.22 \% \\
7.79 \% \\
1.74 \%\end{array}$ \\
\hline
\end{tabular}


Figure 2. CEDE Differences Using Pasquill-Briggs vs Pasquill-Gifford Diffusion Coefficients for an Elevated Release

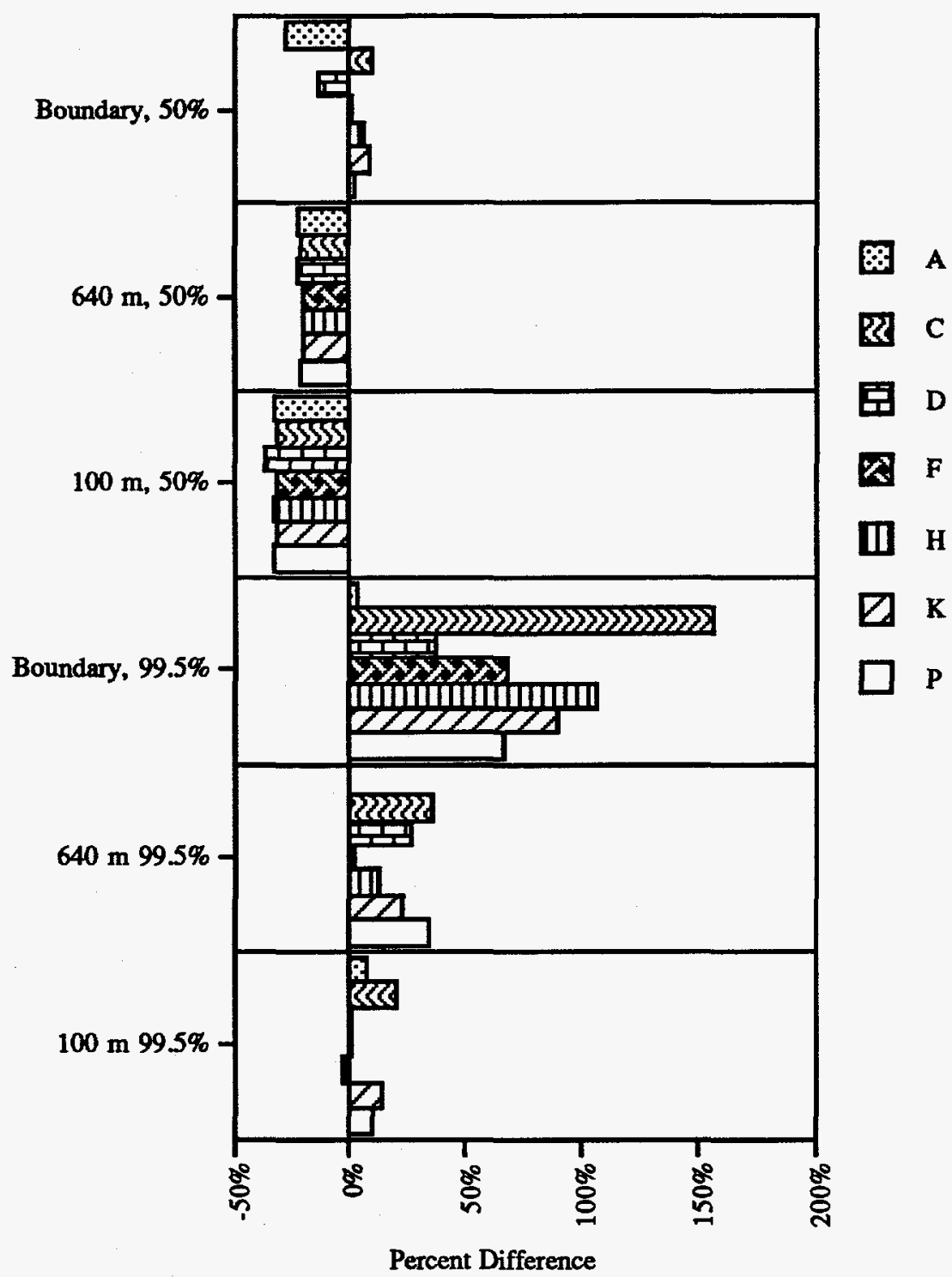

\subsection{Depletion Factors}

Within AXAIRQ, depletion correction factors are calculated using the equations discussed in section 2.3. Depletion correction factors are multiplied by the relative air concentration to reduce the amount of radioactive material in the plume to account for the amount that has deposited. Therefore, the 
depletion correction factor represent the percentage of the plume that remains to expose the individual. Figures 3 through 6 show depletion correction factors for ground level and elevated releases with both particulate and iodine deposition velocities used. The wind speed for all of the calculations was $4.5 \mathrm{~m} / \mathrm{s}$ and Pasquill-Briggs diffusion coefficients were used. The use of another wind speed would result in different graphs.

Figure 3 shows depletion correction factors for a ground-level release by stability category. These curves represent correction factors that are used for releases of tritium and particulates. For ground-level releases, depletion will have the greatest effect for stability category $G$ because of the small values of the vertical diffusion coefficients.

Figure 3. Depletion Correction Factors

Pasquill-Briggs Coefficients

$\left(\mathrm{h}=0 \mathrm{~m}, \mathrm{v}_{\mathrm{d}}=0.001 \mathrm{~m} / \mathrm{s}\right)$
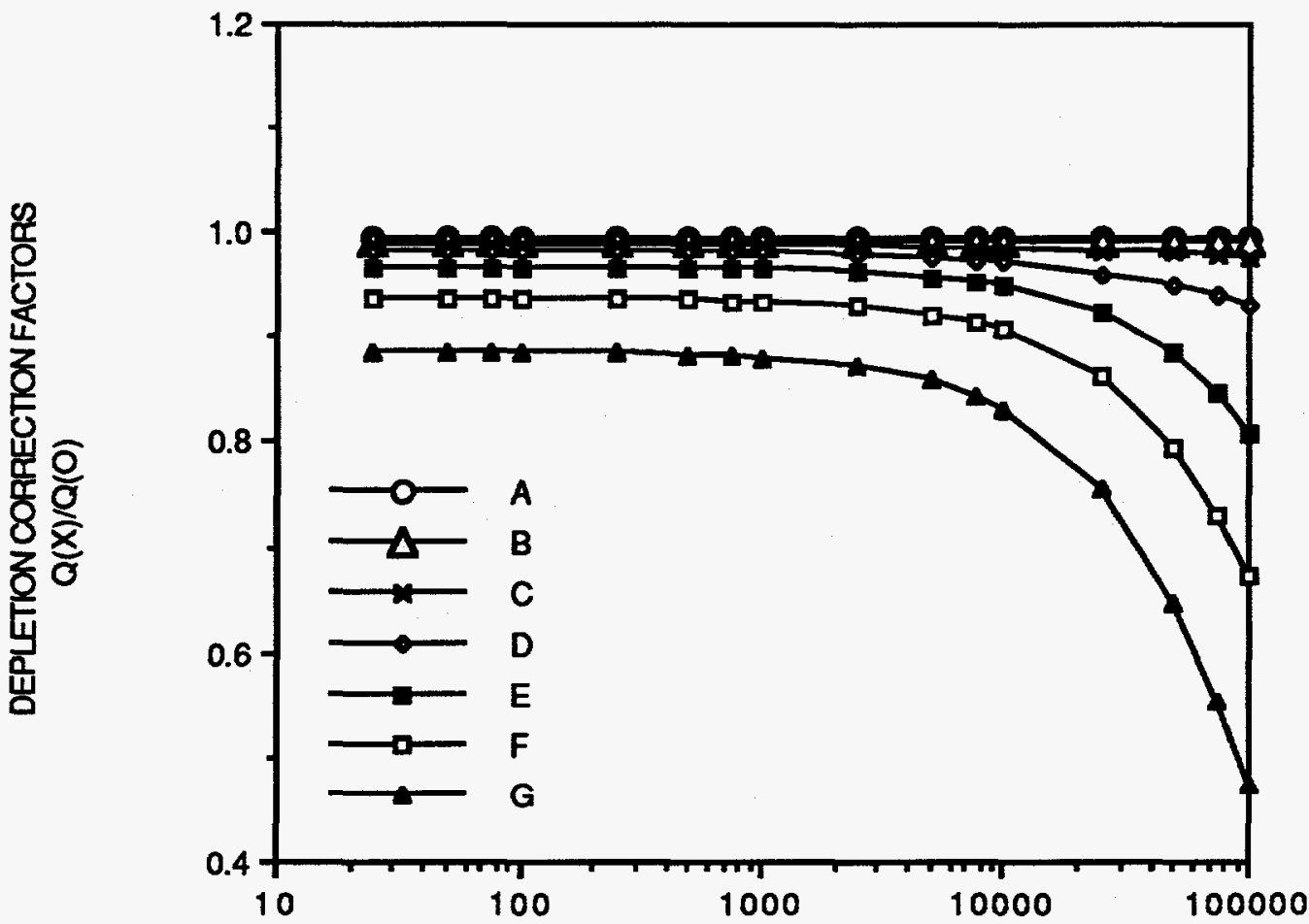

DOWNWIND DISTANCE (m) 
Figure 4 shows depletion correction factors for a ground-level release of iodine by stability category. The curves are more widely spaced because the deposition velocity is an order of magnitude larger than before thus having a greater effect on the depletion correction factors.

Figure 4. Depletion Correction Factors

Pasquill-Briggs Coefficients

$\left(\mathrm{h}=0 \mathrm{~m}, \mathrm{v}_{\mathrm{d}}=0.01 \mathrm{~m} / \mathrm{s}\right.$ )

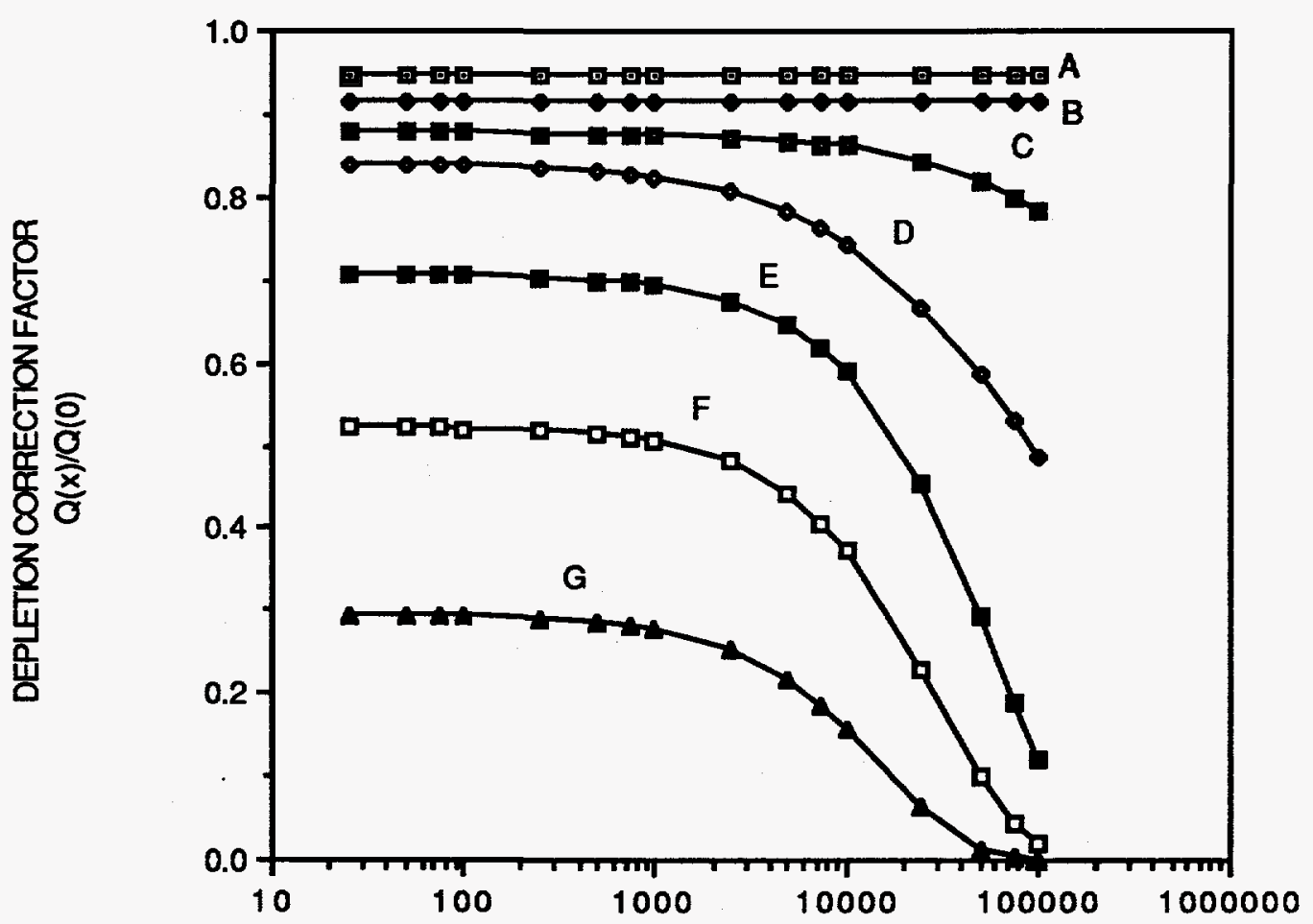

DOWNWIND DISTANCE (m) 
Figure 5 shows the depletion correction factors for elevated release of tritium or particulates. For downwind distances up to $3 \mathrm{~km}$ there is virtually no difference for any of the stability categories. Even at distances of $80 \mathrm{~km}(50$ miles) depletion correction factors have minimal effect with values of approximately 0.9 for stability categories $\mathrm{F}$ and $\mathrm{G}$.

For this example, terrain effects were not considered. Terrain effects decrease the effective plume height and therefore would shift the curves downward. The maximum correction for terrain would reduce the effective height of the plume to zero (ground-level) resulting in the values depicted in Figure 3 for a ground level release.

Figure 5. Depletion Correction Factors

Pasquill-Briggs Coefficients

$\left(\mathrm{h}=61 \mathrm{~m}, \mathrm{v}_{\mathrm{d}}=0.001\right)$

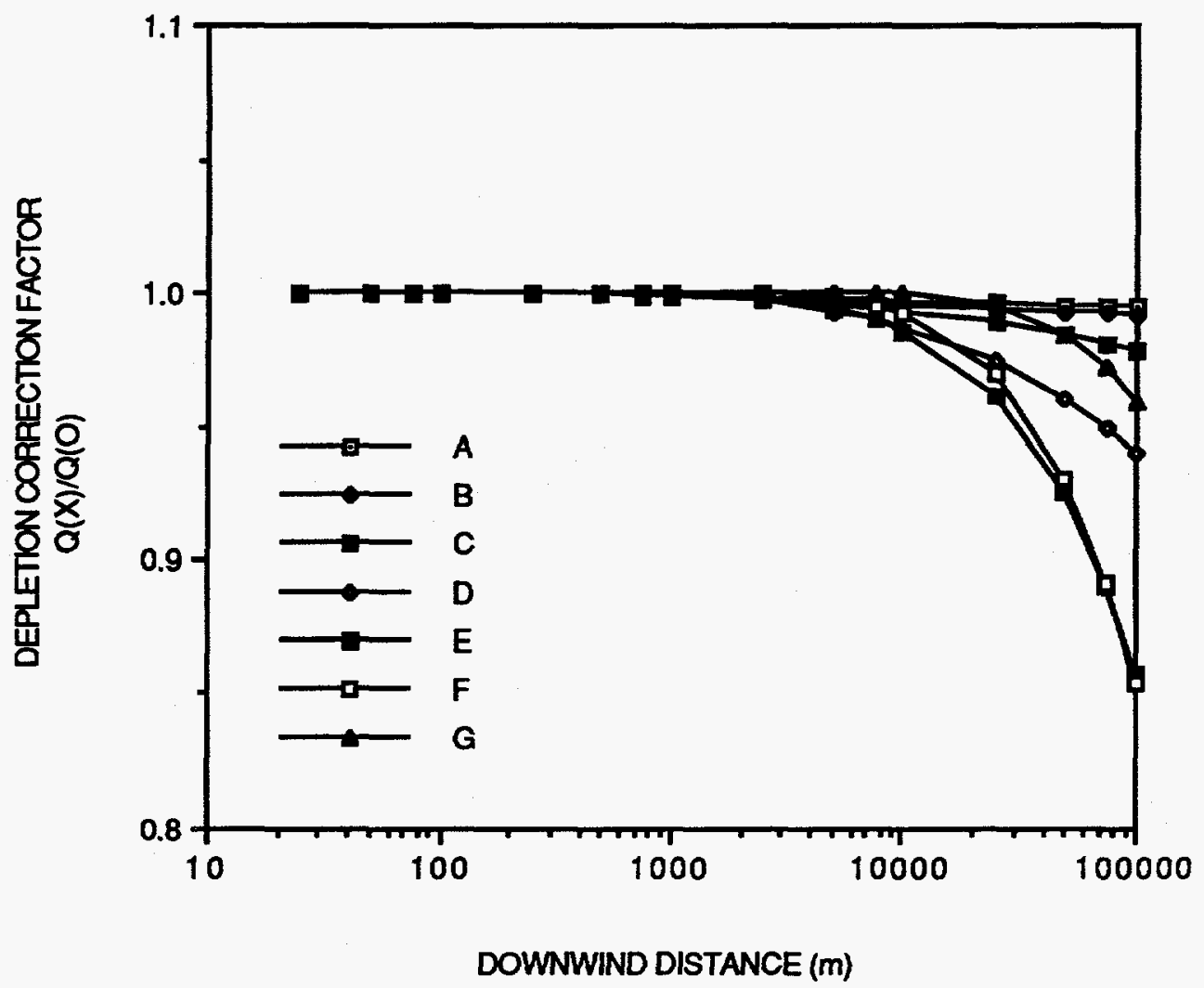


Figure 6 shows the depletion correction factors for iodines from an elevated release height of $61 \mathrm{~m}$. As with the particulates, minimal effect is seen until a downwind distance of $3 \mathrm{~km}$. At distances greater than $10 \mathrm{~km}$ considerable differences are seen in the stable stability categories.

Figure 6. Depletion Correction Factors Pasquill-Briggs Coefficients $\left(\mathrm{h}=61 \mathrm{~m}, \mathrm{v}_{\mathrm{d}}=0.01\right)$

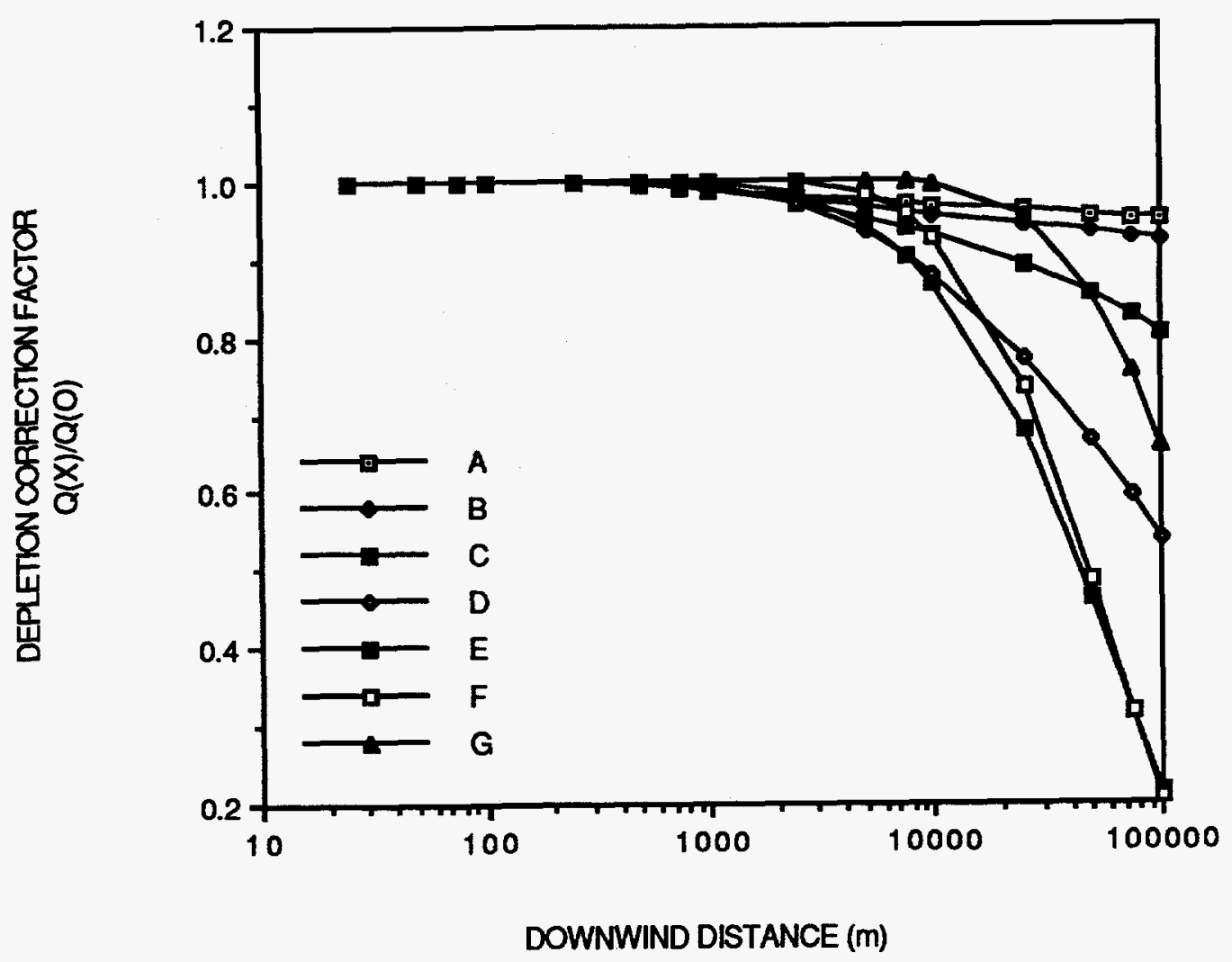


Figure 7 shows the effect of using different wind speeds for stability class G with a deposition velocity of $0.01 \mathrm{~m} / \mathrm{s}$. As shown in this graph, the curves in the previous figures would be shifted down as the wind speed decreased and shifted up as the wind speed increased. The general relationship is indicative of all stability classes. At larger distances, wind speed has less effect as shown by the curves convergence.

Figure 7. Depletion Correction Factors as a Function of Wind Speed (Stability Class G, Pasquill-Briggs Coefficients, $v_{d}=0.01$ )

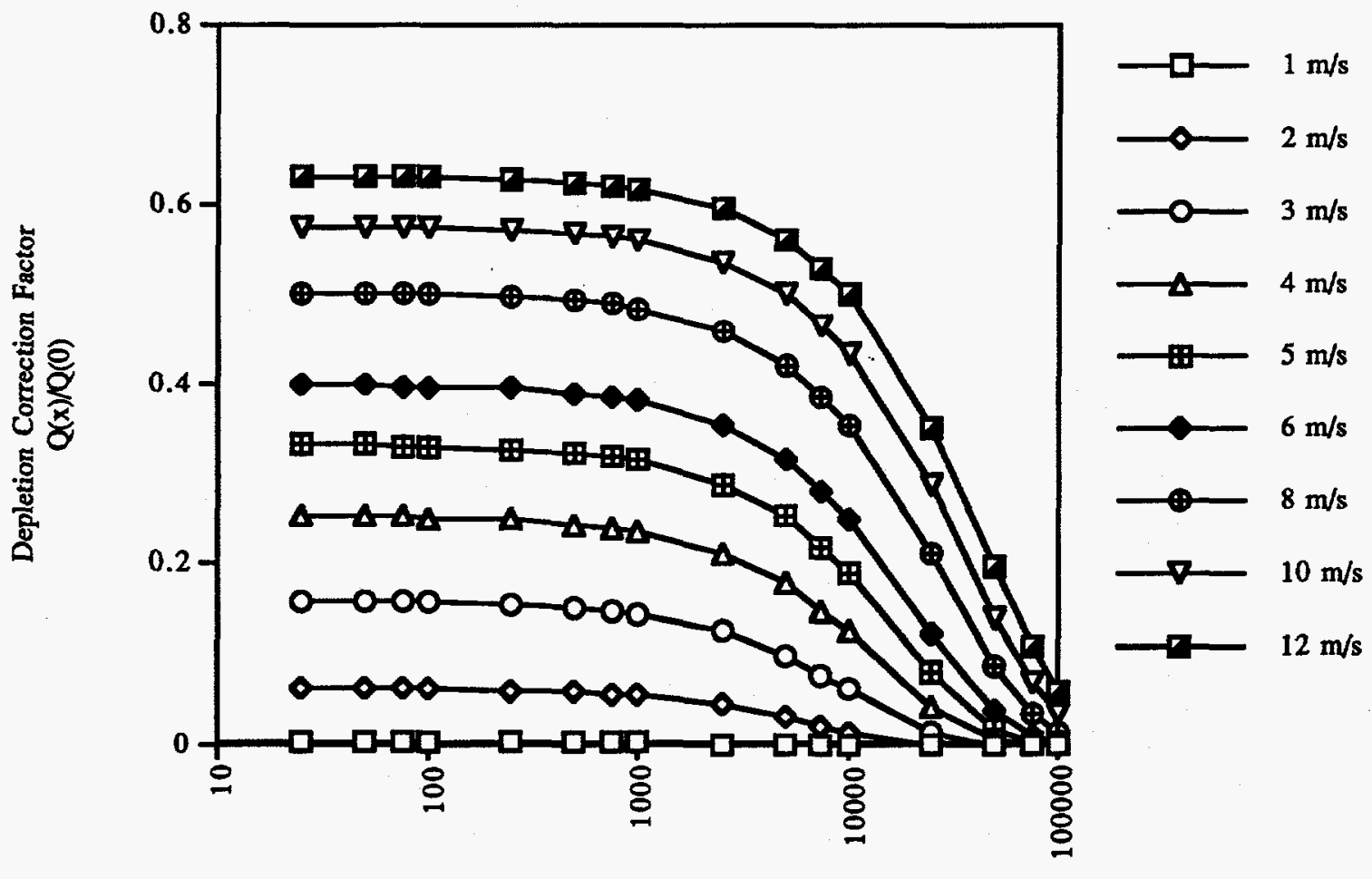

Downwind Distance (m)

\subsection{Hypothetical Accident Scenario Analyzed}

For an indepth comparison of the two versions of the code, a hypothetical accident scenario analyzed for the Foreign Research Reactor (FRR) Environmental Impact Statement (EIS) was used. This accident scenario assumed a dropped fuel assembly and the input parameters used for the analysis are shown in Table 11. 
Table 11. Input for FRR EIS Sample Run

\begin{tabular}{|l|l|l|}
\hline Input Parameter & AXAIR89Q & AXAIRQ \\
\hline Release Location & East 63380 ft & East 63380 ft \\
Vent or Stack & North 71900 ft & North 71900 ft \\
Stack Height & 0 (Stack) & 0 (Stack) \\
Single sector or all sectors & 61 & 61 \\
Meteorological Data (old or new) & NEW (All Sectors) & 0 (All Sectors) \\
Calendar Year of Release & 1994 & NEW \\
Gamma Shine Methodology (0,1,2) & 0 & 1994 \\
Full Daughter Ingrowth & YES & 0 \\
Include 95\% or 50\% Dose & yes(50\%) & YES \\
Do you wish to include deposition & NA & $1(50 \%)$ \\
Diffusion Coefficients 1-PB, 2-PG & NA (PG) & YES \\
Mixing Height & NA & 1 \\
Dose Factor Library & 30 & $1000 \mathrm{~m}$ \\
Number of user distances & $2(0.06,0.4$ miles) & $2(0.06,0.4$ miles) \\
Printout Type & BOTH & BOTH \\
Release & (All 2 hr) & $($ All 2 hr) \\
& $2.12 \mathrm{Ci} \mathrm{H-3}$ & $2.12 \mathrm{Ci} \mathrm{H-3}$ \\
& $59.7 \mathrm{Ci} \mathrm{Kr-85}$ & $59.7 \mathrm{Ci} \mathrm{Kr-85}$ \\
& $2.93 \mathrm{E}-3 \mathrm{Ci} \mathrm{I-129}$ & $2.93 \mathrm{E}-3 \mathrm{Ci} \mathrm{I-129}$ \\
\hline
\end{tabular}

For the first comparison, AXAIR89Q and AXAIRQ were executed using identical input parameters as shown under the AXAIR89Q subheading of Table 11. The results of this comparison are shown in Table 12. As expected, the two versions of AXAIR produced identical results. 
Table 12. AXAIR89Q vs AXAIRQ for FRR EIS Dropped Assembly Scenario (Conditions are Identical)

\begin{tabular}{|c|c|c|c|}
\hline Output Parameter & $\begin{array}{c}\text { AXAIR89Q } \\
\text { Result } \\
\text { (rem or } \\
\text { person rem) }\end{array}$ & $\begin{array}{c}\text { AXAIRQ } \\
\text { Result } \\
\text { (rem or } \\
\text { person rem) }\end{array}$ & $\begin{array}{c}\text { \% Difference } \\
\text { AXQ-AX89Q } \\
\text { AX89Q }\end{array}$ \\
\hline $\begin{array}{c}\text { Offsite Maximum Individual } \\
99.5 \% \text { Met }\end{array}$ & $1.67 \mathrm{E}-06$ & $1.67 \mathrm{E}-06$ & $0.0 \%$ \\
\hline $\begin{array}{c}\text { Offsite Maximum Individual } \\
50.0 \% \text { Met }\end{array}$ & $2.28 \mathrm{E}-07$ & $2.28 \mathrm{E}-07$ & $0.0 \%$ \\
\hline $\begin{array}{c}\text { Worst Case 100 m } \\
99.5 \% \text { Met }\end{array}$ & $1.04 \mathrm{E}-03$ & $1.04 \mathrm{E}-03$ & $0.0 \%$ \\
\hline $\begin{array}{c}\text { Worst Case 100 m } \\
50 \% \text { Met }\end{array}$ & $3.90 \mathrm{E}-04$ & $3.90 \mathrm{E}-04$ & $0.0 \%$ \\
\hline $\begin{array}{c}\text { Worst Case 640 m } \\
99.5 \% \text { Met }\end{array}$ & $3.98 \mathrm{E}-05$ & $3.98 \mathrm{E}-05$ & $0.0 \%$ \\
\hline $\begin{array}{c}\text { Worst Case 640 m } \\
50 \% \text { Met }\end{array}$ & $1.29 \mathrm{E}-05$ & $1.29 \mathrm{E}-05$ & $0.0 \%$ \\
\hline $\begin{array}{c}\text { Offsite Population } \\
\text { Onsite Populations }\end{array}$ & $1.35 \mathrm{E}-02$ & $1.35 \mathrm{E}-02$ & $0.0 \%$ \\
\hline & $4.49 \mathrm{E}-03$ & $4.49 \mathrm{E}-03$ & $0.0 \%$ \\
\hline
\end{tabular}

For the next comparison, the mixing height for AXAIRQ was increased to $1000 \mathrm{~m}$ and AXAIR89Q used the hard-coded value of $200 \mathrm{~m}$ with all other parameters held constant. Table 13 shows the effects on CEDE of increasing the mixing height to $1000 \mathrm{~m}$. Close in to the release point $(100 \mathrm{~m}$ and $640 \mathrm{~m})$, no differences are seen for either the CEDEs for meteorological conditions not exceeded $99.5 \%$ or $50 \%$ of the time. At the boundary, no difference is noted in the 99.5\% CEDE. All of these doses show no difference due to the small values of $\sigma_{\mathrm{z}}$ associated with the calculations.

Mixing height will only affect the CEDEs for values of $\sigma_{\mathrm{z}}>0.8^{*}$ (mixing height). At the site boundary, which is approximately $11 \mathrm{~km}$ from the release point, neutral and even unstable stability categories are likely to be associated with the determination of the 50\% CEDE. The vertical diffusion coefficients associated with these stability classes will be larger and therefore increase dispersion and reduce dose. The offsite population is negatively affected because the distances at which the calculations are performed is so great (up to $80 \mathrm{~km}$ ) and larger diffusion coefficients are associated with these larger distances.

Table 14 shows the effects on the CEDEs of applying Pasquill-Briggs diffusion coefficients over Pasquill-Gifford with all other parameters held constant. All 99.5\% CEDEs increased and all of the 50\% CEDEs decreased. The more stable stability categories show a greater difference in diffusion coefficients for Pasquill-Gifford vs Pasquill-Briggs than the neutral or unstable categories. 
Table 13. AXAIR89Q vs AXAIRQ for FRR EIS Dropped Assembly Scenario (No Deposition, PG, Mixing Height $1000 \mathrm{~m}$ )

\begin{tabular}{|c|c|c|c|}
\hline Output Parameter & $\begin{array}{c}\text { AXAIR89Q } \\
\text { Result } \\
\text { (rem or } \\
\text { person rem) }\end{array}$ & $\begin{array}{c}\text { AXAIRQ } \\
\text { Result } \\
\text { (rem or } \\
\text { person rem) }\end{array}$ & $\begin{array}{c}\text { \% Difference } \\
\text { AXQ-AX89Q } \\
\text { AX89Q }\end{array}$ \\
\hline $\begin{array}{c}\text { Offsite Maximum Individual } \\
\text { 99.5\% Met }\end{array}$ & $1.67 \mathrm{E}-06$ & $1.67 \mathrm{E}-06$ & $0.0 \%$ \\
\hline $\begin{array}{c}\text { Offsite Maximum Individual } \\
50.0 \% \text { Met }\end{array}$ & $2.28 \mathrm{E}-07$ & $6.18 \mathrm{E}-08$ & $-72.9 \%$ \\
\hline $\begin{array}{c}\text { Worst Case 100 m } \\
99.5 \% \text { Met }\end{array}$ & $1.04 \mathrm{E}-03$ & $1.04 \mathrm{E}-03$ & $0.0 \%$ \\
\hline $\begin{array}{c}\text { Worst Case 100 m } \\
50 \% \text { Met }\end{array}$ & $3.90 \mathrm{E}-04$ & $3.90 \mathrm{E}-04$ & $0.0 \%$ \\
\hline $\begin{array}{c}\text { Worst Case 640 m } \\
99.5 \% \text { Met }\end{array}$ & $3.98 \mathrm{E}-05$ & $3.98 \mathrm{E}-05$ & $0.0 \%$ \\
\hline $\begin{array}{c}\text { Worst Case 640 m } \\
50 \% \text { Met }\end{array}$ & $1.29 \mathrm{E}-05$ & $1.29 \mathrm{E}-05$ & $0.0 \%$ \\
\hline Offsite Population & $1.35 \mathrm{E}-02$ & $9.92 \mathrm{E}-03$ & $-26.5 \%$ \\
\hline Onsite Populations & $4.49 \mathrm{E}-03$ & $4.48 \mathrm{E}-03$ & $-0.2 \%$ \\
\hline
\end{tabular}

Table 14. AXAIR89Q vs AXAIRQ for FRR EIS Dropped Assembly Scenario (No Deposition, PB, Mixing Height $200 \mathrm{~m}$ )

\begin{tabular}{|c|c|c|c|}
\hline Output Parameter & $\begin{array}{c}\text { AXAIR89Q } \\
\text { Result } \\
\text { (rem or } \\
\text { person rem) }\end{array}$ & $\begin{array}{c}\text { AXAIRQ } \\
\text { Result } \\
\text { (rem or } \\
\text { person rem) }\end{array}$ & $\begin{array}{c}\text { \% Difference } \\
\text { AXQ-AX89Q }\end{array}$ \\
\hline $\begin{array}{c}\text { Offsite Maximum Individual } \\
\text { 99.5\% Met }\end{array}$ & $1.67 \mathrm{E}-06$ & $3.10 \mathrm{E}-06$ & $85.6 \%$ \\
\hline $\begin{array}{c}\text { Offsite Maximum Individual } \\
50.0 \% \text { Met }\end{array}$ & $2.28 \mathrm{E}-07$ & $2.54 \mathrm{E}-07$ & $11.4 \%$ \\
\hline $\begin{array}{c}\text { Worst Case 100 m } \\
99.5 \% \text { Met }\end{array}$ & $1.04 \mathrm{E}-03$ & $1.65 \mathrm{E}-03$ & $58.7 \%$ \\
\hline $\begin{array}{c}\text { Worst Case 100 m } \\
50 \% \text { Met }\end{array}$ & $3.90 \mathrm{E}-04$ & $2.37 \mathrm{E}-04$ & $-39.2 \%$ \\
\hline $\begin{array}{c}\text { Worst Case 640 m } \\
99.5 \% \text { Met }\end{array}$ & $3.98 \mathrm{E}-05$ & $5.99 \mathrm{E}-05$ & $50.5 \%$ \\
\hline $\begin{array}{c}\text { Worst Case 640 m } \\
50 \% \text { Met }\end{array}$ & $1.29 \mathrm{E}-05$ & $7.66 \mathrm{E}-06$ & $-40.6 \%$ \\
\hline Offsite Population & $1.35 \mathrm{E}-02$ & $1.37 \mathrm{E}-02$ & $1.5 \%$ \\
\hline Onsite Populations & $4.49 \mathrm{E}-03$ & $4.64 \mathrm{E}-03$ & $3.3 \%$ \\
\hline
\end{tabular}


For the next comparison, the deposition option is invoked in AXAIRQ and all other parameters are the same for the two codes. The results of this comparison are shown in Table 15. Depletion automatically occurs when deposition is considered. For this case, depletion caused an overall negative effect on the resulting doses. No ground shine dose is contributed from any of the three nuclides released. Both tritium and krypton do not contribute to ground shine on any occasion. Iodine-129 has a very long half life $(1.6 \mathrm{E}+07$ years) and, therefore, does not contribute significantly to ground shine dose. If a different iodine nuclide had been released, the contribution from ground shine could possibly outweigh the reduction in dose due to plume depletion. Differences increase with distances because plume depletion increases as a function of downwind distance from the release location.

Table 15. AXAIR89Q vs AXAIRQ for FRR EIS Dropped Assembly Scenario (Deposition, PG, Mixing Height $200 \mathrm{~m}$ )

\begin{tabular}{|c|c|c|c|}
\hline Output Parameter & $\begin{array}{c}\text { AXAIR89Q } \\
\text { Result } \\
\text { (rem or } \\
\text { person rem) }\end{array}$ & $\begin{array}{c}\text { AXAIRQ } \\
\text { Result } \\
\text { (rem or } \\
\text { person rem) }\end{array}$ & $\begin{array}{c}\text { \% Difference } \\
\text { AXQ-AX89Q } \\
\text { AX89Q }\end{array}$ \\
\hline $\begin{array}{c}\text { Offsite Maximum Individual } \\
99.5 \% \text { Met }\end{array}$ & $1.67 \mathrm{E}-06$ & $7.87 \mathrm{E}-07$ & $-52.9 \%$ \\
\hline $\begin{array}{c}\text { Offsite Maximum Individual } \\
50.0 \% \text { Met }\end{array}$ & $2.28 \mathrm{E}-07$ & $1.73 \mathrm{E}-07$ & $-24.1 \%$ \\
\hline $\begin{array}{c}\text { Worst Case 100 m } \\
99.5 \% \text { Met }\end{array}$ & $1.04 \mathrm{E}-03$ & $1.03 \mathrm{E}-03$ & $-1.0 \%$ \\
\hline $\begin{array}{c}\text { Worst Case 100 m } \\
50 \% \text { Met }\end{array}$ & $3.90 \mathrm{E}-04$ & $3.88 \mathrm{E}-04$ & $-0.5 \%$ \\
\hline $\begin{array}{c}\text { Worst Case 640 m } \\
99.5 \% \text { Met }\end{array}$ & $3.98 \mathrm{E}-05$ & $3.59 \mathrm{E}-05$ & $-9.8 \%$ \\
\hline $\begin{array}{c}\text { Worst Case 640 m } \\
50 \% \text { Met }\end{array}$ & $1.29 \mathrm{E}-05$ & $1.22 \mathrm{E}-05$ & $-5.4 \%$ \\
\hline Offsite Population & $1.35 \mathrm{E}-02$ & $4.69 \mathrm{E}-03$ & $-62.3 \%$ \\
\hline \begin{tabular}{c} 
Onsite Populations \\
\hline
\end{tabular} & $4.49 \mathrm{E}-03$ & $3.92 \mathrm{E}-03$ & $-12.7 \%$ \\
\hline
\end{tabular}


Table 16 shows the effect of invoking all of the new features: deposition, Pasquill-Briggs diffusion coefficients, and mixing height increased to $1000 \mathrm{~m}$. A decrease in CEDE is seen for all receptors except the $99.5 \%$ maximally exposed individual at $100 \mathrm{~m}$ and $640 \mathrm{~m}$. These distances see an increase in dose due to the Pasquill-Briggs diffusion coefficients. For all other CEDEs, a reduction is seen primarily due to plume depletion of the radionuclides. For the 50\% doses close to the release point, the decrease is from the use of Pasquill-Briggs over Pasquill-Gifford diffusion coefficients .

Table 16. AXAIR89Q vs AXAIRQ for FRR EIS Dropped Assembly Scenario (Deposition, PB, Mixing Height 1000 m)

\begin{tabular}{|c|c|c|c|}
\hline Output Parameter & $\begin{array}{c}\text { AXAIR89Q } \\
\text { Result } \\
\text { (rem or } \\
\text { person rem) }\end{array}$ & $\begin{array}{c}\text { AXAIRQ } \\
\text { Result } \\
\text { (rem or } \\
\text { person rem) }\end{array}$ & $\begin{array}{c}\text { \% Difference } \\
\text { AXQ-AX89Q } \\
\text { AX89Q }\end{array}$ \\
\hline $\begin{array}{c}\text { Offsite Maximum Individual } \\
99.5 \% \text { Met }\end{array}$ & $1.67 \mathrm{E}-06$ & $1.24 \mathrm{E}-06$ & $-25.75 \%$ \\
\hline $\begin{array}{c}\text { Offsite Maximum Individual } \\
50.0 \% \text { Met }\end{array}$ & $2.28 \mathrm{E}-07$ & $6.41 \mathrm{E}-08$ & $-71.89 \%$ \\
\hline $\begin{array}{c}\text { Worst Case 100 m } \\
99.5 \% \text { Met }\end{array}$ & $1.04 \mathrm{E}-03$ & $1.65 \mathrm{E}-03$ & $58.65 \%$ \\
\hline $\begin{array}{c}\text { Worst Case 100 m } \\
50 \% \text { Met }\end{array}$ & $3.90 \mathrm{E}-04$ & $2.36 \mathrm{E}-04$ & $-39.49 \%$ \\
\hline $\begin{array}{c}\text { Worst Case 640 m } \\
99.5 \% \text { Met }\end{array}$ & $3.98 \mathrm{E}-05$ & $5.12 \mathrm{E}-05$ & $28.64 \%$ \\
\hline $\begin{array}{c}\text { Worst Case 640 m } \\
50 \% \text { Met }\end{array}$ & $1.29 \mathrm{E}-05$ & $7.28 \mathrm{E}-06$ & $-43.57 \%$ \\
\hline $\begin{array}{c}\text { Offsite Population } \\
\text { Onsite Populations }\end{array}$ & $1.35 \mathrm{E}-02$ & $4.15 \mathrm{E}-03$ & $-69.26 \%$ \\
\hline & $4.49 \mathrm{E}-03$ & $4.00 \mathrm{E}-03$ & $-10.91 \%$ \\
\hline
\end{tabular}


Figure 8 shows a compilation of the results from Tables 13-16. This is representative of only this scenario and would not be typical of releases from various areas. The bottom block of the figure shows the effect of the changes for the 99.5\% maximally exposed offsite individual CEDE. The total impact is negative, even though applying Pasquill-Briggs coefficients leads to an increase. The overall decrease occurs because deposition is dependent on the diffusion coefficients and mixing height and therefore, when multiple features are applied the effects are not additive.

Figure 8. Percent Differences Applying New AXAIRQ Features For FRR EIS Accident Scenario

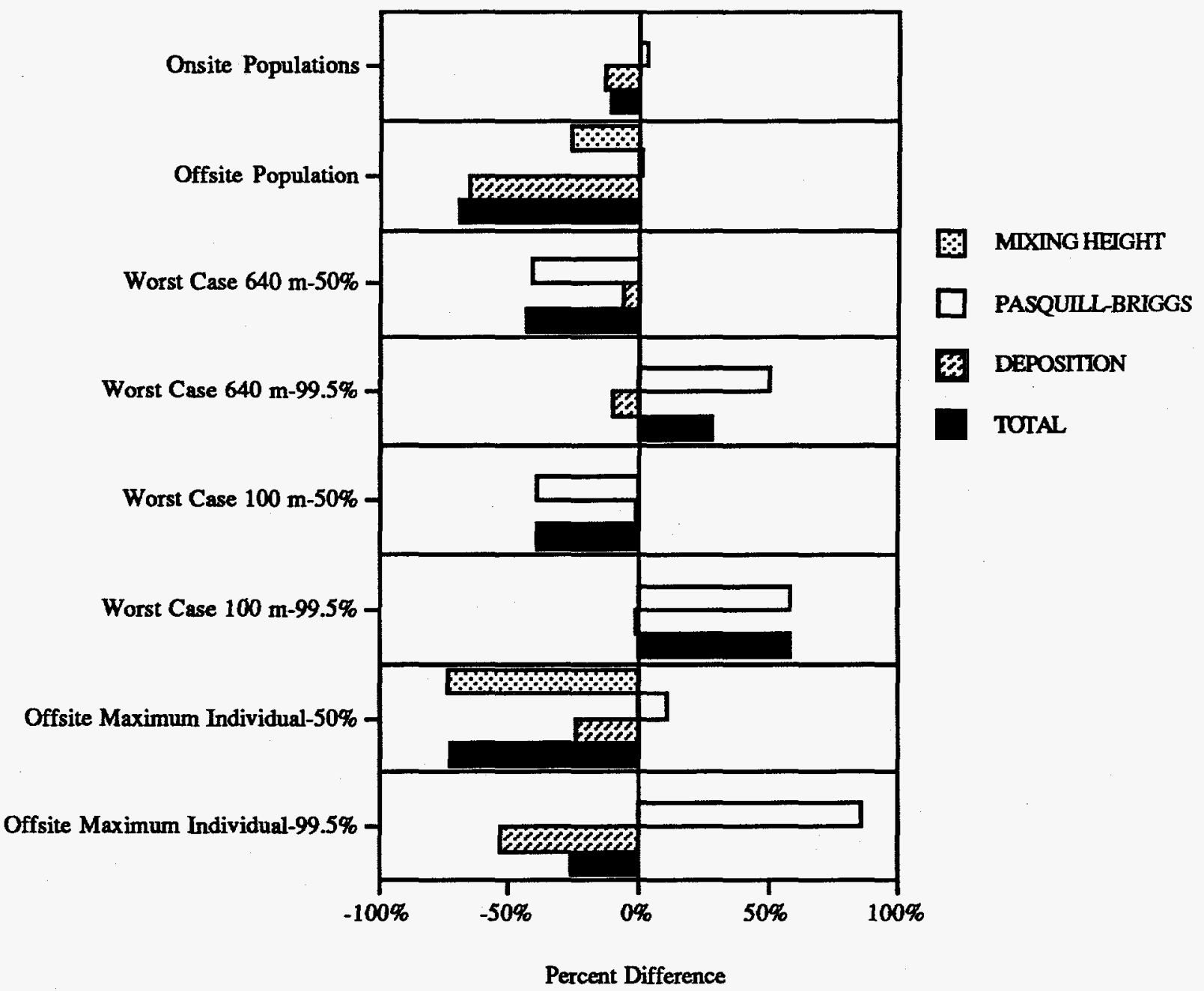




\subsection{Hypothetical Center-of-Site Releases}

A center-of-site release was analyzed using nuclides with different deposition velocities. Table 17 shows the input parameters that were used to perform the analysis. Both stack and vent releases were analyzed. As before, each of the new features were analyzed separately and then collectively.

Table 17. Input for Hypothetical Center-of-Site Release

\begin{tabular}{|l|l|l|}
\hline Input Parameter & AXAIR89Q & AXAIRQ \\
\hline Release Location & East 58000 ft & East 58000 ft \\
Vent or Stack & North 62000 ft & North 62000 ft \\
Stack Height & 0 (Stack), 1(Vent) & 0 (Stack), 1(Vent) \\
Single sector or all sectors & 61 & 61 \\
Meteorological Data (old or new) & NEW (All Sectors) & 0 (All Sectors) \\
Calendar Year of Release & 1995 & NEW \\
Gamma Shine Methodology (0,1,2) & 0 & 1995 \\
Full Daughter Ingrowth & YES & 0 \\
Include 95\% or 50\% Dose & yes(50\%) & 1 (50\%) \\
Do you wish to include deposition & NA & YES/NO \\
Diffusion Coefficients 1-PB, 2-PG & NA (PG) & $1 / 2$ \\
Mixing Height & NA (200 m) & $1000 \mathrm{~m} / 200 \mathrm{~m}$ \\
Dose Factor Library & 30 & 30 \\
Number of user distances & $2(0.06,0.4 \mathrm{miles)}$ & 2 (0.06, 0.4 miles) \\
Printout Type & BOTH & BOTH \\
Release & Separate Runs & Separate Runs \\
& 1 Ci H-3, 2 hr & 1 Ci H-3, 2 hr \\
& 1 Ci I-131, 2hr & 1 Ci I-131, 2hr \\
& 1 Ci Pu-238, 2 hr & 1 Ci Pu-238, 2 hr \\
\hline
\end{tabular}


For a ground-level release of tritium from the center of the site, the effect of applying new AXAIRQ features is depicted in Figure 9 for various hypothetical receptors. While ground shine dose from tritium is not a pathway of importance, plume depletion is allowed to occur downwind of the release point, therefore, the dose with deposition decreased when compared with AXAIR89Q for the maximally exposed offsite individual. The maximally exposed offsite individual, at all release locations, showed an increase in CEDE for meteorological conditions not exceeded $99.5 \%$ of the time, due to the use of Pasquill-Briggs diffusion coefficients. The same effect is seen at $100 \mathrm{~m}$ and $640 \mathrm{~m}$ from the release point for $99.5 \%$ meteorological conditions. All other potential receptors show a decrease in CEDE primarily due to the deposition option.

Figure 9. Percent Differences from Applying New AXAIRQ Features for Ground-Level Center-of-Site Release of H-3

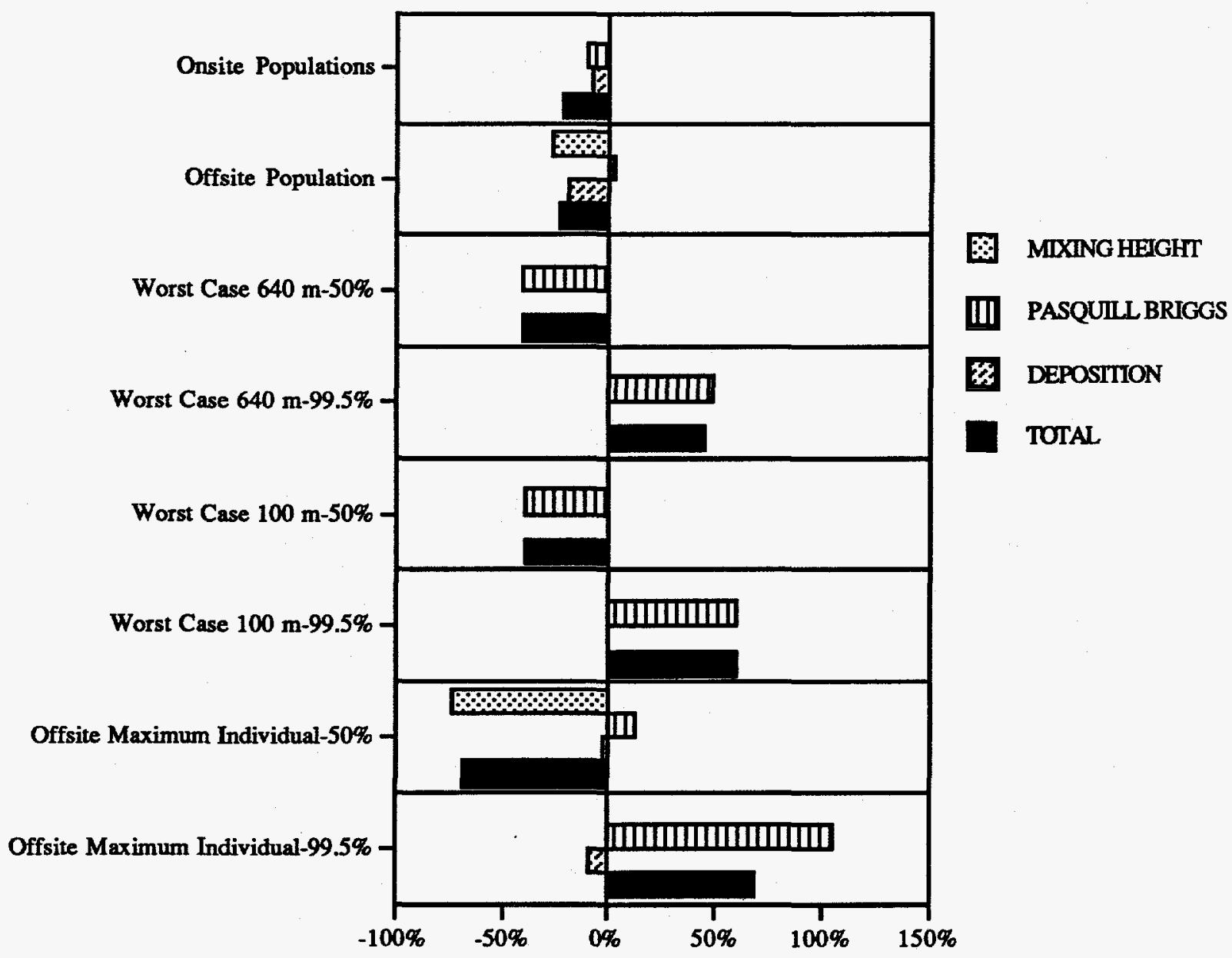

PERCENT DIFFERENCE 
For a release of tritium with a stack height of $61 \mathrm{~m}$ the effect of applying the new features in AXAIRQ is shown in Figure 10. The total dose shows a decrease for all hypothetical receptors except 50\% CEDE $100 \mathrm{~m}$ from the source and offsite maximally exposed individual. The maximum offsite individual differs by more than $100 \%$ by using Pasquill-Briggs diffusion coefficients over Pasquill-Gifford. The 50\% CEDE at $100 \mathrm{~m}$ shows a large difference. The resulting doses are actually 5.83E-18 mrem using PasquillGifford diffusion coefficients and 1.40E-16 mrem using Pasquill-Briggs diffusion coefficients which corresponds to a $2300 \%$ difference. The reason for such a large difference is explained next.

For this particular case the calculations are sensitive to the value of the vertical diffusion coefficient. For non-fumigation conditions with a stack release, relative air concentration is calculated using the following equation:

$$
\frac{\chi}{Q}=\frac{e^{-\left(\frac{\left(h_{c}\right)^{2}}{2 \sigma_{z}^{2}}\right)}}{\pi \sigma_{y} \sigma_{z} U_{H S}}
$$

where:

$$
\begin{aligned}
\chi / Q & =\text { the dispersion factor }\left(\mathrm{sec} / \mathrm{m}^{3}\right) \\
h_{\mathbf{e}} & =\text { effective release height }(\mathrm{m}) \\
\mathrm{U}_{\mathrm{HS}} & =\text { wind speed at the release height }(\mathrm{m} / \mathrm{sec}) \\
\sigma_{\mathrm{y}} & =\text { horizontal diffusion coefficient }(\mathrm{m}) \\
\sigma_{\mathrm{Z}} & =\text { vertical diffusion coefficient }(\mathrm{m})
\end{aligned}
$$

For a downwind distance of $100 \mathrm{~m}$, using Pasquill-Gifford diffusion coefficients results in $\sigma_{\mathrm{z}}=7.50 \mathrm{~m}$ and using Pasquill-Briggs diffusion coefficients results in $\sigma_{\mathrm{z}}=7.92 \mathrm{~m}$ (see section 2.1 for equations). While these two numbers are in close agreement (5\% difference), when substituted into the exponent displayed in the numerator of equation 11, the following results are seen for a $61 \mathrm{~m}$ effective plume height:

Pasquill-Gifford:

$$
e^{-\left(\frac{h_{0}^{2}}{2 \sigma_{z}^{2}}\right)}=e^{-\left(\frac{62^{2}}{2 * 7.5^{2}}\right)}=1.45 e-15
$$

Pasquill-Briggs

$$
e^{-\left(\frac{h_{c}^{2}}{2 \sigma_{z}^{2}}\right)}=e^{-\left(\frac{61^{2}}{2 * 7.92^{2}}\right)}=1.31 \mathrm{e}-13
$$

A 5\% increase in vertical diffusion coefficient value leads to a factor of 90 increase in the exponential term within the equation. Other factors, such as wind speed, also will affect the differences. These differences are likely to be great for: 1)small diffusion coefficients, 2)release heights that are fairly high $(>50 \mathrm{~m})$, and 3)small resulting doses. Also, due to small values that are involved, the percent difference is magnified. 
Figure 10. Percent Differences Applying New AXAIRQ Features for an Elevated Center of the Site Release of $\mathrm{H}-3$

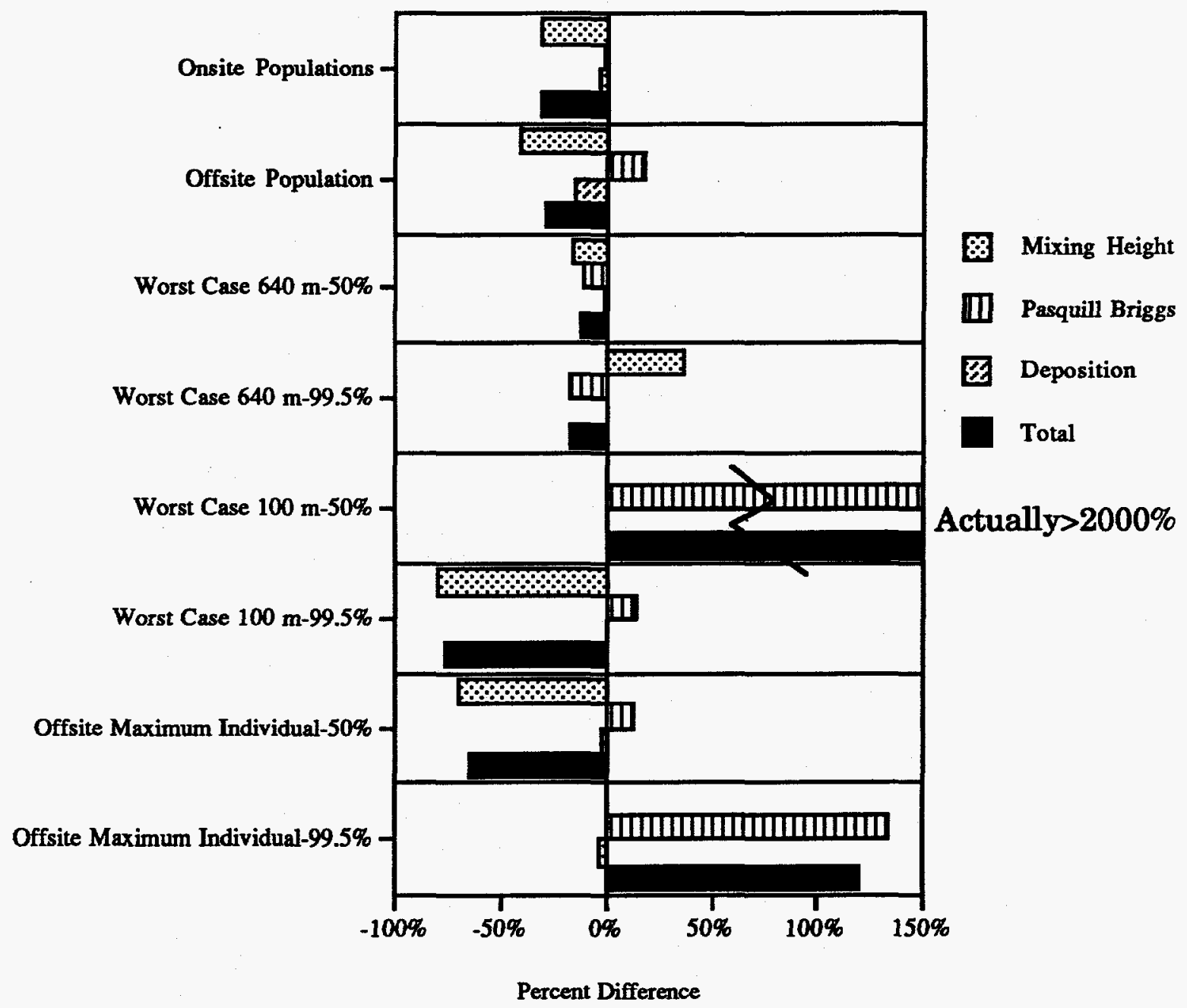


Figure 11 shows the result of employing AXAIRQ's new features for a groundlevel release of I-131 from the center-of-site. Iodine has a greater deposition velocity than particulates and, therefore, depletion has a greater effect on the results. At receptor locations that are close to the release point, the increase in CEDE by using Pasquill-Briggs diffusion coefficients is greater than the decrease in CEDE from plume depletion so an overall increase is shown. At greater distances, the reduction in CEDE due to plume depletion is greater than both the increase due to ground shine and increase from applying Pasquill-Briggs diffusion coefficients.

Figure 11. Percent Difference Applying New AXAIRQ Features for I-131 Ground-Level Center-of-Site Release

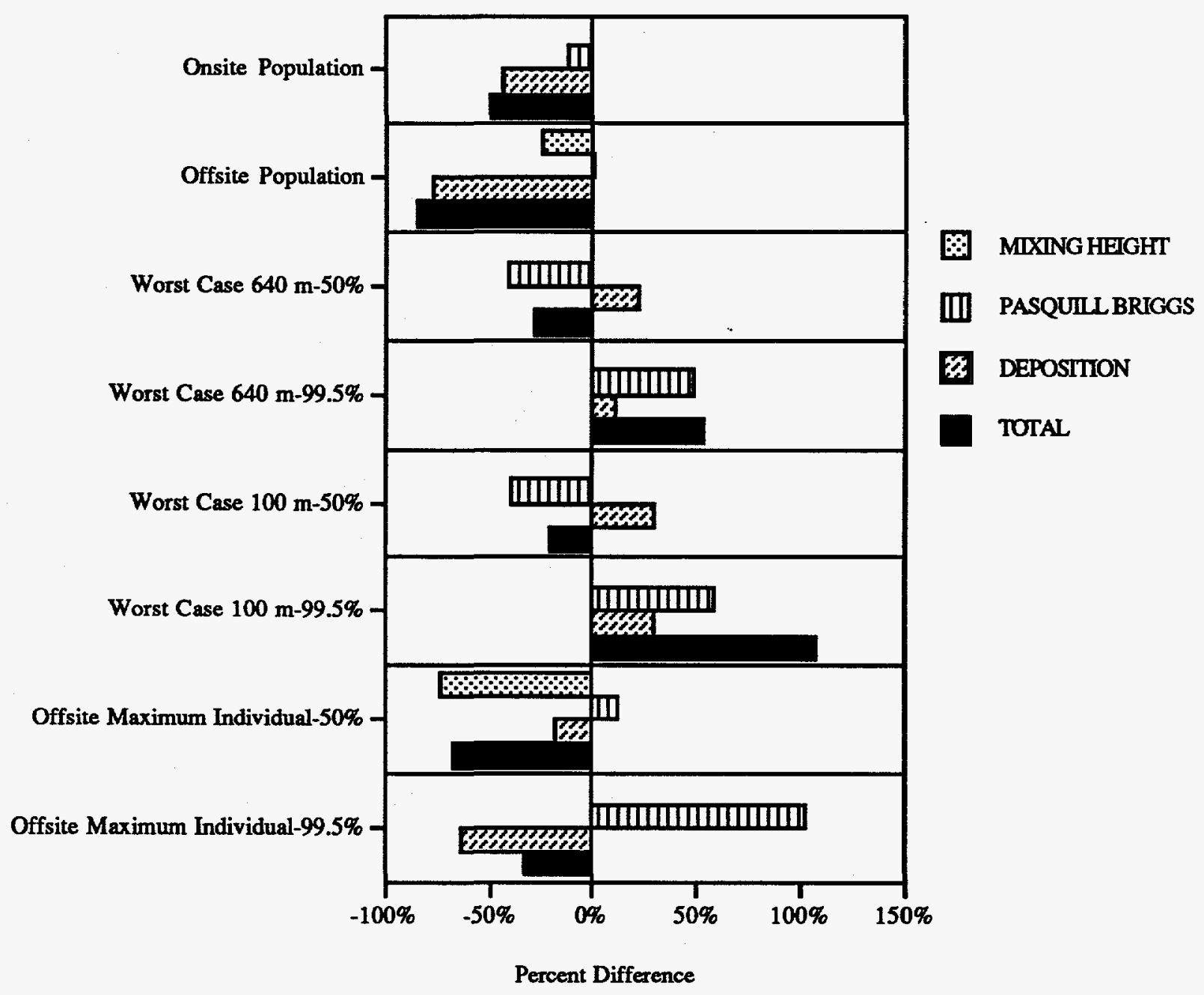


Figure 12 shows the result of applying new AXAIRQ features for an elevated release of I-131 from the center-of-site. Referring back to Figures 4 and 6 for a deposition velocity of $0.01 \mathrm{~m} / \mathrm{s}$ as release height increases, the depletion correction factor decreases. For the maximally exposed offsite individual, the effects of deposition are not large enough to counterbalance the effects of changed diffusion coefficients so a net increase in CEDE is exhibited.

For the 50\% meteorological conditions with the receptor $100 \mathrm{~m}$ from the release point, the changes were so slight $(<1 \%)$ that the differences are not visible on the bar graph.

Figure 12. Percent Difference Applying New AXAIRQ Features for I-131 Elevated Release from Center-of-Site

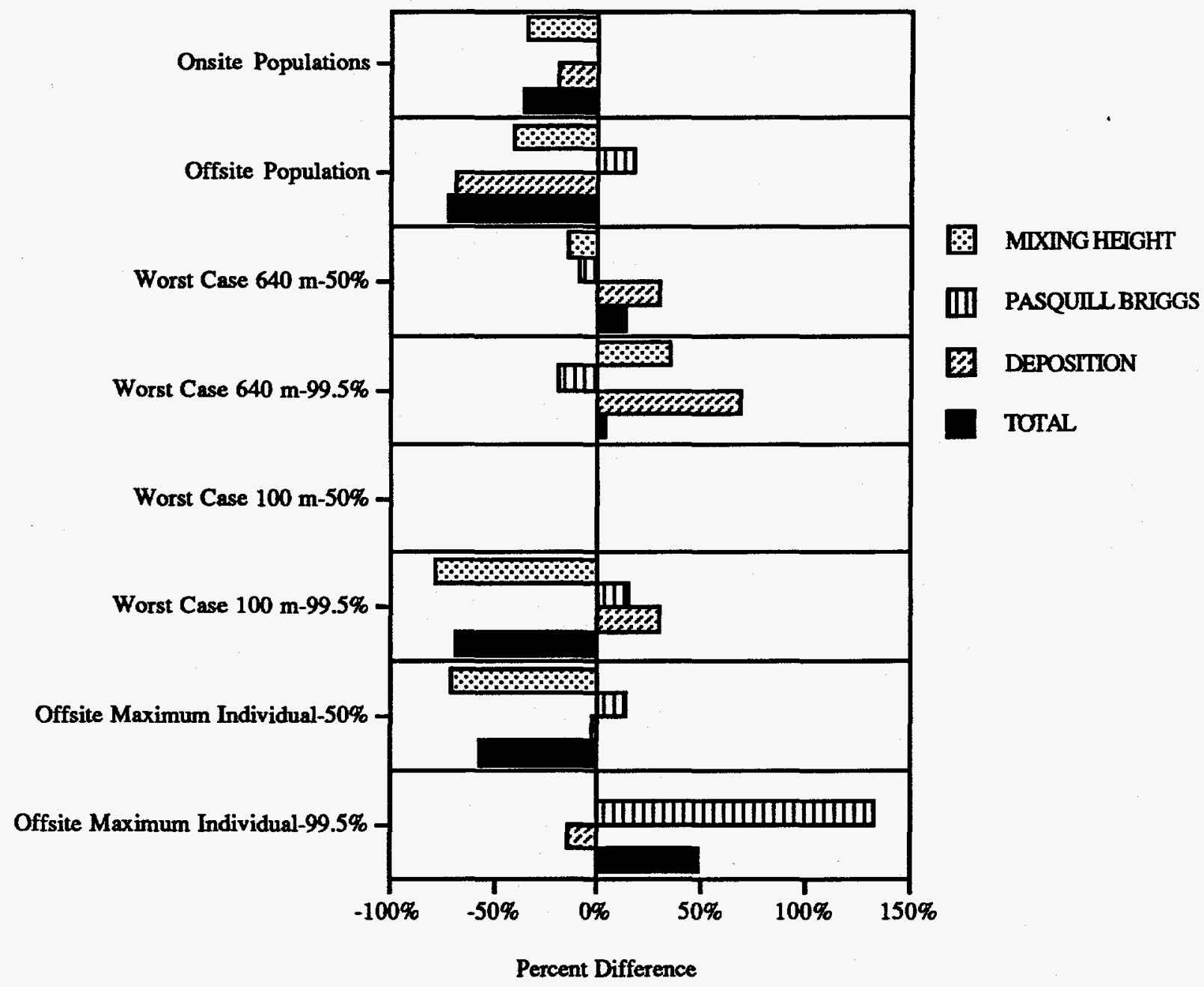


Figure 13 shows the expected differences in CEDE for a ground-level release of $\mathrm{Pu}-238$ from the center-of-site. The overall effect for the maximally exposed offsite individual is an increase in CEDE primarily due to the change in the diffusion coefficients. Figure 13 is similar to Figure 9 because both nuclides are assigned the same deposition velocity and ground shine dose is zero for tritium and negligible for Pu-238.

Figure 13. Percent Difference Applying New AXAIRQ Features for Pu-238 Ground-Level Release from Center-of-Site

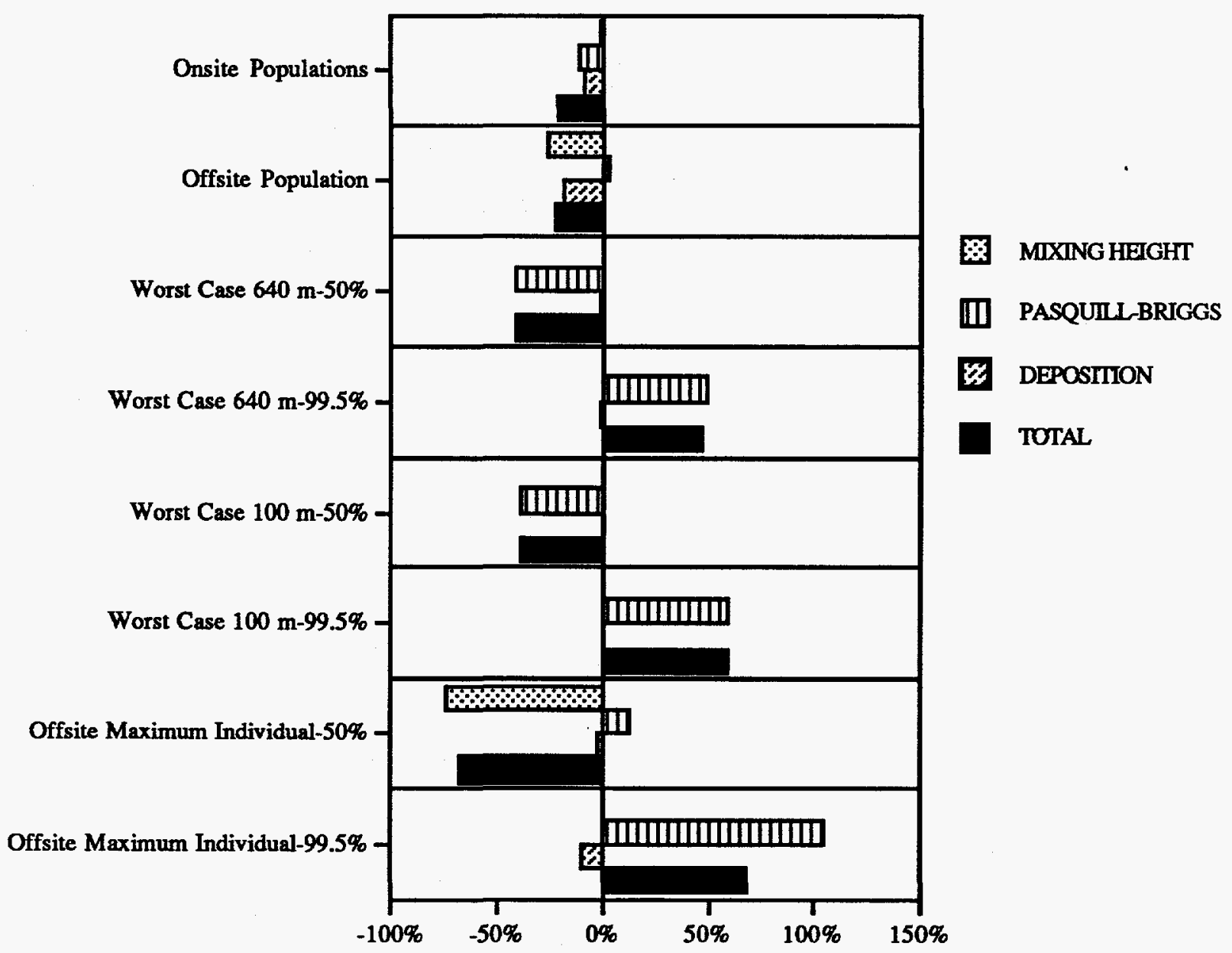

Percent Difference 
Figure 14 shows the expected differences in CEDE for an elevated release of $\mathrm{Pu}-238$ from the center-of-site. The overall effect for the maximally exposed offsite individual is an increase due to the change in the diffusion coefficients. Figure 14 is similar to Figure 10 except for the $100 \mathrm{~m}$ receptor point for $50 \%$ meteorological conditions. The differences are not nearly as large for $\mathrm{Pu}-238$ as for tritium because of the meteorological conditions associated with the $50 \%$ doses.

Figure 14. Percent Difference Applying New AXAIRQ Features for Pu-238 Elevated Release from Center-of-Site

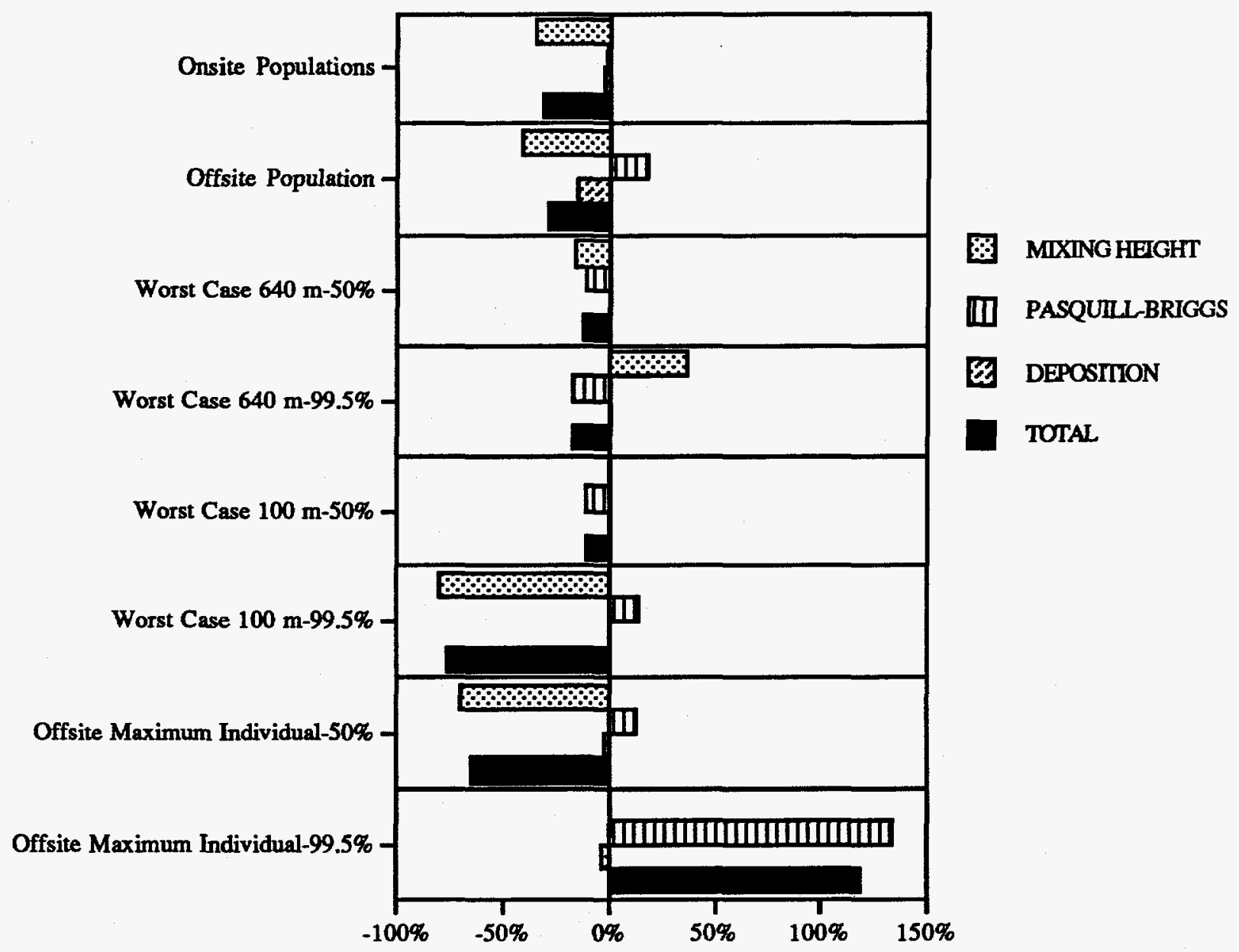

Percent Difference 


\subsection{CONCLUSIONS}

A wide range of different results from applying the new features that are available within AXAIRQ. Based on the limited number of cases studied, general statements can be made about these specific runs. The following statements will not be indicative of every possible combination of AXAIRQ input values.

1) Pasquill-Briggs vs Pasquill-Gifford coefficients will result in higher CEDEs at greater distances.

2) Application of the deposition option lowers the CEDE because of depletion of the plume.

Differences will result with each set of unique input parameters that are used. The user should select the input parameters that are best suited for the particular hypothetical accident that is being analyzed regardless of the effect that the parameters have on the resulting CEDE. 


\subsection{REFERENCES}

Briggs, G. A. 1973 Diffusion estimation for small emissions, in Environmental Research Laboratory, Air Resources Atmospheric Turbulence and Diffusion Laboratory, Annual Report, ATDL-106, USDOC-NOAA.

DOE 1988 External Dose-Rate Conversion Factors for Calculation of Dose to the Public, DOE/EH-0070, U.S. Department of Energy, Washington, DC.

Eimutis, E.C. and Konicek, M.G. 1972 "Derivations of Continuous Functions for the Lateral and Vertical Atmospheric Dispersion Coefficients", Atmospheric Environment, Vol. 6, pp. 559-563.

EPA 1991 Manual of Protection Action Guides and Protective Actions for Nuclear Incidents, EPA-R-92-001, U.S. Environmental Protection Agency, October.

Feinhals, J. and Bunnenberg, C. 1988 "Laboratory Investigations of HTO Deposition to Soils", Fusion Technology, Volume 14, September.

Garrett, A.J. 1981 "Comparison of Observed Mixed-Layer Depths to Model Estimates Using Observed Temperatures and Winds, and MOS Forecasts", Journal of Applied Meteorology, November 1981.

Garrett, A. J. and C. E. Murphy, Jr. 1981 A Puff-Plume Atmospheric Deposition Model for Use at SRP in Emergency Response Situations, DP-1595, E. I. du Pont de Nemours \& Co., Savannah River Laboratory, Aiken, SC.

Hamby, D.M. 1990a Verification of AXAIR89Q, WSRC-RP-90-1222, Westinghouse Savannah River Company, Aiken, SC.

Hanna, S.R., Briggs, G.A. and Hosker Jr., R.P. 1982 Handbook on Atmospheric Diffusion. DOE/TIC-11223 (DE82002045) Technical Information Center U.S. DOE.

Murphy, C.E. and Pendergast, M.M. 1970 "Environmental Transport and Cycling of Tritium in the Vicinity of Atmospheric Releases", Behavior of Tritium in the Environment, International Atomic Energy Agency, Vienna.

NRC 1972 Onsite Meteorological Programs, U.S. NRC Regulatory Guide 1.23, U.S. Nuclear Regulatory Commission, Washington, DC, February 
NRC 1982 Atmospheric Dispersion Models for Potential Accident Consequence Assessments at Nuclear Power Plants, U.S. NRC Regulatory Guide 1.145 , U.S. Nuclear Regulatory Commission, Washington, DC, Rev. 1, November .

Parker, M.J. and Addis, R.P. 1993 Meteorological Monitoring Program(U), WSRC-TR-93-0106, Westinghouse Savannah River Company, Aiken, SC.

Pasquill, F. 1976 Atmospheric Dispersion Parameters in Gaussian Plume Modeling: Part II. Possible Requirements for Change in the Turner Workbook Values, Report EPA-600/4-76306, U.S. Environmental Protection Agency.

Simpkins, A.A. 1994 Justification for Change in AXAIR Dispersion Coefficients, WSRC-RP-94-96, Westinghouse Savannah River Company, Aiken, SC.

Simpkins, A.A. 1995a AXAIRQ User's Manual, WSRC-RP-95-709, Westinghouse Savannah River Company, Aiken, SC.

Simpkins, A.A. 1995b Verification of AXAIRQ, WSRC-RP-95-708, Westinghouse Savannah River Company, Aiken, SC.

Slade, D.H. 1968 Meteorology and Atomic Energy, D.H. Slade (ed.), TID24190, U.S. Atomic Energy Commission, Oak Ridge, Tennessee, 1968.

Walker, F.W. 1983, D.G. Miller, and F. Feiner, Chart of Nuclides Thirteenth Edition, General Electric Company, San Jose, CA. 